\title{
Carbon monoxide: a critical quantitative analysis and review of the extent and limitations of its second messenger function
}

This article was published in the following Dove Press journal:

Clinical Pharmacology:Advances and Applications

26 February 2015

Number of times this article has been viewed

\author{
David G Levitt' \\ Michael D Levitt ${ }^{2}$ \\ 'Department of Integrative Biology \\ and Physiology, University of \\ Minnesota, Minneapolis, MN, USA; \\ ${ }^{2}$ Research Service, Veterans Affairs \\ Medical Center, Minneapolis, MN, USA
}

\begin{abstract}
Endogenously produced carbon monoxide (CO) is commonly believed to be a ubiquitous second messenger involved in a wide range of physiological and pathological responses. The major evidence supporting this concept is that $\mathrm{CO}$ is produced endogenously via heme oxygenase-catalyzed breakdown of heme and that experimental exposure to $\mathrm{CO}$ alters tissue function. However, it remains to be conclusively demonstrated that there are specific receptors for $\mathrm{CO}$ and that endogenous $\mathrm{CO}$ production is sufficient to alter tissue function. Unlike other signaling molecules, $\mathrm{CO}$ is not significantly metabolized, and it is removed from cells solely via rapid diffusion into blood, which serves as a near infinite sink. This non-metabolizable nature of $\mathrm{CO}$ renders the physiology of this gas uniquely susceptible to quantitative modeling. This review analyzes each of the steps involved in CO signaling: 1) the background CO partial pressure $\left(\mathrm{P}_{\mathrm{CO}}\right)$ and the blood and tissue $\mathrm{CO}$ binding; 2$)$ the affinity of the putative $\mathrm{CO}$ receptors; 3 ) the rate of endogenous tissue $\mathrm{CO}$ production; and 4) the tissue $\mathrm{P}_{\mathrm{CO}}$ that results from the balance between this endogenous $\mathrm{CO}$ production and diffusion to the blood sink. Because existing data demonstrate that virtually all endogenous $\mathrm{CO}$ production results from the routine "housekeeping" turnover of heme, only a small fraction can play a signaling role. The novel aspect of the present report is to demonstrate via physiological modeling that this small fraction of $\mathrm{CO}$ production is seemingly insufficient to raise intracellular $\mathrm{P}_{\mathrm{CO}}$ to the levels required for the conventional, specific messenger receptor activation. It is concluded that the many physiological alterations observed with exogenous $\mathrm{CO}$ administration are probably produced by the non-specific $\mathrm{CO}$ inhibition of cytochrome $\mathrm{C}$ oxidase activity, with release of reactive oxygen species (ROS) and that this ROS signaling pathway is a potential effector mechanism for endogenously produced $\mathrm{CO}$.
\end{abstract}

Keywords: cytochrome, oxygenase, Krogh cylinder model, ROS, heme

\section{Introduction}

Scientific appreciation of the physiological implications of carbon monoxide (CO) has evolved from its recognition as an environmental toxin in $1857,{ }^{1}$ to demonstration of its derivation from heme catabolism in $1952,{ }^{2}$ to its present important status as an intracellular messenger that regulates hundreds of physiological and cytoprotective functions. $\mathrm{CO}$ is produced in animals exclusively by heme oxygenase (HO) catalysis of heme to biliverdin: ${ }^{3}$

$\mathrm{Heme}+3 \mathrm{O}_{2}+3.5 \mathrm{NADPH}+3.5 \mathrm{H}^{+} \stackrel{\mathrm{HO}}{\rightarrow} \mathrm{CO}+$ biliverdin $+\mathrm{Fe}^{2+}+3.5 \mathrm{NADP}^{+}+3 \mathrm{H}_{2} \mathrm{O}$

(1)
Correspondence: David G Levitt, Department of Integrative Biology and Physiology, University of Minnesota, 6-I 25 Jackson Hall, 32I Church St S E, Minneapolis, MN 55455, USA

Tel + I 6126257649

Fax+l 6126255149

Email levit00I@umn.edu 
In mammals, there are two forms of HO: an inducible form, HO-1 (also known as heat-shock protein 32), and a constitutive form, HO-2. A wide variety of stimuli induce HO-1, including oxidative stress, heat shock, ischemia, radiation, hypoxia, hyperoxia, and drugs. ${ }^{4-6}$ This amazing responsiveness to nearly every known cell-modifying signal has focused attention on the potential importance of $\mathrm{HO}$ in a wide range of clinical conditions. It is important to recognize that alterations in $\mathrm{HO}$ do not necessarily implicate $\mathrm{CO}$ as the HO effector, since HO has three other functions: removal of heme, release of $\mathrm{Fe}^{2+}$, and production of the anti-oxidant bilirubin from biliverdin, all of which are important cellular responses to stress and cell death. ${ }^{7}$ However, it is widely assumed that the primary effect of $\mathrm{HO}$ induction is the modification of cell function via production of $\mathrm{CO}$, which serves as a second messenger. The focus of this review will be on the unique physiology required for $\mathrm{CO}$ to serve as the second messenger mediator of $\mathrm{HO}$ activity - a function invoked as a factor in a wide variety of clinical conditions. For example, a recent review of just the central nervous system conditions in which $\mathrm{CO}$ is implicated include Alzheimer's disease, Parkinson's disease, multiple sclerosis, cerebral artery occlusion, and pain. ${ }^{8}$

The CO messenger literature is enormous, involving nearly every organ and regulatory system. There are a number of excellent recent reviews of this topic, ${ }^{5-13}$ with each review having a particular focus and emphasis. Seemingly lacking in these discussions is a critical examination of the unusual features of $\mathrm{CO}$ that complicate the ability of this gas to serve as a typical intracellular messenger. Most signaling molecules are produced solely for a signaling purpose and are then rapidly catabolized (eg, nitric oxide has a half-time of less than 2 seconds), and the background intracellular activity of the signaling molecule is maintained at a very low level. In contrast, there is minimal catabolism of $\mathrm{CO}$, and endogenously produced $\mathrm{CO}$ is removed from the cell entirely via diffusion to the blood, where it is avidly bound by hemoglobin $(\mathrm{Hb})$. Homeostasis of blood CO is established by pulmonary excretion, a relatively slow process with a half-time of approximately 4 hours (as discussed in the " $\mathrm{Hb}$ and $\mathrm{Mb} \mathrm{CO}$ binding and pharmacokinetics" section). Thus, cells float in a sea of the messenger, which maintains a low, but not negligible-free $\mathrm{CO}$ concentration in the cell equal to that of blood, about $0.002 \mu \mathrm{M}$, or a CO partial pressure $\left(\mathrm{P}_{\mathrm{CO}}\right)$ of $0.0019 \mathrm{mmHg}$ under normal conditions (Table 1 ). To provide a signal, $\mathrm{CO}$ has to be produced at a rate that appreciably raises the $\mathrm{CO}$ concentration over the basal level, ruling out the possibility that trivial $\mathrm{CO}$ production could serve as a messenger.
Table I Physiological CO parameters (at $37^{\circ} \mathrm{C}$ )

\begin{tabular}{|c|c|c|c|}
\hline Parameter & Value & Ref & Comments \\
\hline \multicolumn{3}{|l|}{ Aqueous solubility $(\alpha)$} & At $37^{\circ} \mathrm{C}$ \\
\hline $\mathrm{mL} \mathrm{STP/liter/mmHg}$ & 0.024 & 68 & \\
\hline$\mu \mathrm{mole} / \mathrm{liter} / \mathrm{mmHg}$ & I.I & & \\
\hline \multirow{2}{*}{\multicolumn{3}{|c|}{$\begin{array}{l}\text { Aqueous diffusion } \\
\text { coefficient (D) }\end{array}$}} & Interpolate \\
\hline & & & between $30^{\circ} \mathrm{C}$ \\
\hline & & & and $40^{\circ} \mathrm{C}$ \\
\hline $\mathrm{cm}^{2} / \mathrm{s}$ & $3.26 \times 10^{-5}$ & 108 & \\
\hline \multicolumn{4}{|l|}{ Aqueous diffusivity } \\
\hline \multicolumn{4}{|l|}{$\left(K_{w}=\alpha D\right)$} \\
\hline $\mathrm{nmol} / \mathrm{cm} / \mathrm{mm} \mathrm{Hg} / \mathrm{s}$ & $3.58 \times 10^{-5}$ & & \\
\hline \multicolumn{4}{|l|}{ Tissue CO diffusivity $(\mathrm{K})$} \\
\hline $\mathrm{nmol} / \mathrm{cm} / \mathrm{mm} \mathrm{Hg} / \mathrm{s}$ & $1.77 \times 10^{-5}$ & 109 & $\begin{array}{l}\text { From } \mathrm{K} \text { for } \mathrm{O}_{2} \\
\text { divided by } \mathrm{I} .32\end{array}$ \\
\hline \multicolumn{4}{|l|}{$\mathrm{CO} / \mathrm{O}_{2}$ relative affinity $(\mathrm{M})$} \\
\hline Hemoglobin & 220 & 14 & \\
\hline Myoglobin & 39 & 14 & \\
\hline Cytochrome $\mathrm{C}$ oxidase & 2.5 & 29 & \\
\hline Blood CO concentration & & & Normal human \\
\hline \% Carboxyhemoglobin & 0.8 & 18 & \\
\hline $\mathrm{P}_{\mathrm{CO}}(\mathrm{mmHg})$ & 0.0019 & & $\begin{array}{l}\text { Estimated } \\
\text { from M for } \\
\text { hemoglobin }\end{array}$ \\
\hline End alveolar $\mathrm{P}_{\mathrm{CO}}(\mathrm{mmHg})$ & 0.0018 & 17 & \\
\hline Free concentration $(\mu \mathrm{M})$ & 0.002 & & $\begin{array}{l}\text { Estimated from } \\
\mathrm{P}_{\mathrm{co}} \text { and } \alpha\end{array}$ \\
\hline \multicolumn{4}{|l|}{$\begin{array}{l}P_{c o} \text { for biological effect } \\
(\mathrm{mmHg})\end{array}$} \\
\hline $\begin{array}{l}\text { Superoxide dismutase } \\
\text { synthesis }\end{array}$ & 0.0076 & 42 & I h exposure \\
\hline ROS-related cell death & 0.076 & 42 & I h exposure \\
\hline Piglet pial arteriolar dilation & 0.09 & 60 & \\
\hline Rat tail artery dilation & 10 & 62 & \\
\hline
\end{tabular}

Abbreviations: STP, standard temperature and pressure; ref, reference; ROS, reactive oxygen species; $\mathrm{P}_{\mathrm{CO}}$, $\mathrm{CO}$ partial pressure; $\mathrm{h}$, hour.

The lack of catabolism of CO, its removal from the cell by diffusion to the blood, and its excretion solely via the lungs makes CO uniquely amenable to quantitative physiological modeling. For example, in contrast to other messengers, the total body production of $\mathrm{CO}$ is easily assessed (via breath measurements), and the intracellular $\mathrm{P}_{\mathrm{CO}}$ at baseline and following $\mathrm{CO}$ administration both can be determined, since intracellular $\mathrm{P}_{\mathrm{CO}}$ is in equilibrium with the blood $\mathrm{P}_{\mathrm{CO}}$. Most important, the diffusion of $\mathrm{CO}$ between the cell and blood can be quantitatively modeled, making it possible to estimate the intracellular production rate required to maintain a given cellular $\mathrm{P}_{\mathrm{CO}}$. In Table 1, we have summarized the fundamental physical chemical CO parameters (eg, solubility, diffusion coefficient) and the range of $\mathrm{CO}$ concentrations required for different biological effects.

The fundamental (but rarely stated) hypothesis of CO signaling is that local tissue $\mathrm{CO}$ production raises the local 
cellular concentration to a level sufficiently above the background concentration to trigger the signaling, which is then terminated when the tissue production ceases and the $\mathrm{CO}$ diffuses to the blood sink. The crucial issue is whether the rate of tissue production is sufficient to reach signaling levels, given the rapid rate of diffusion between cells and the blood sink. In order to answer this question, the following items require careful consideration: 1) the background blood and tissue $\mathrm{CO} ; 2$ ) the $\mathrm{CO}$ affinity of the putative tissue $\mathrm{CO}$ signaling receptors; 3 ) the rate of endogenous tissue $\mathrm{CO}$ production; and 4) a quantitative analysis of the tissue $\mathrm{CO}$ concentration that is reached as a result of this $\mathrm{CO}$ production in the presence of the nearly infinite diffusion sink represented by the blood. This review will present what we believe to be the first detailed, quantitative discussions of each of these issues.

The " $\mathrm{Hb}$ and $\mathrm{Mb} \mathrm{CO}$ binding and pharmacokinetics" section reviews the quantitative details of the binding of $\mathrm{CO}$ to $\mathrm{Hb}$ and myoglobin $(\mathrm{Mb})$ and the pharmacokinetics of $\mathrm{CO}$ production, distribution, and excretion. This binding determines the steady state background $\mathrm{CO}$ concentration and the time dependence of its change when $\mathrm{CO}$ is exogenously administered.

Two fundamentally different receptor mechanisms have been proposed for $\mathrm{CO}$ second messenger signaling. The first, discussed in the "COX binding and ROS formation" section, is the $\mathrm{CO}$ binding to and inhibition of cellular cytochrome $\mathrm{C}$ oxidase (COX), a reaction which releases reactive oxygen species (ROS) that serve as a relatively non-specific effector. This type of "signaling" is unique to $\mathrm{CO}$ and raises the question of whether it is actually a physiological mechanism versus a non-specific toxic $\mathrm{CO}$ action. This issue is particularly important, because most recent research concerning the mode of action of inhaled $\mathrm{CO}$ invokes the mechanism of ROS formation secondary to COX inhibition. The second signaling mechanism is the classic second messenger type involving binding to a specific $\mathrm{CO}$ receptor which then triggers a unique cellular response. The "Specific CO sensors or receptors" section reviews the $\mathrm{CO}$ receptors that have been proposed, their affinity for $\mathrm{CO}$, and the evidence supporting their second messenger function.

The "HO activity, heme substrate concentration, and the endogenous rate of $\mathrm{CO}$ tissue production" section reviews available information about the rate of endogenous tissue $\mathrm{CO}$ production that might serve a messenger function. There have been only a few, inexact measurements of this critical factor that determines the tissue $\mathrm{CO}$ concentration. In this review, it will be stressed that the vast majority of the total $\mathrm{CO}$ produced in the body results from the routine turnover of $\mathrm{Hb}$ and other tissue (eg, hepatic) hemes; only a very small fraction of the total $\mathrm{CO}$ endogenous production possibly could be designed to serve a specific $\mathrm{CO}$ signaling function.

The "Quantitative modeling of the steady state and timedependent tissue CO in the presence of the blood sink" section describes a quantitative model of the steady state and time-dependent tissue $\mathrm{CO}$ concentrations that result from the balance between the endogenous tissue $\mathrm{CO}$ production and the rate of diffusion to the blood sink. This calculation is designed to mimic the physiological effect of local tissue $\mathrm{HO}$ activity. Although the model is a crude approximation of the complicated tissue-blood interaction, it provides the first analysis of the basic requirements necessary for a $\mathrm{CO}$ signaling mechanism, in particular, the large rates of local endogenous $\mathrm{CO}$ production required for signaling.

Finally, the "Discussion: does HO function via its release of CO?" section summarizes the results of this analysis and their implications for interpreting the function and importance of $\mathrm{CO}$ signaling. This analysis places limits on the possible second messenger role of $\mathrm{CO}$ and raises questions about the validity of some conventionally accepted views of CO signaling.

\section{$\mathrm{Hb}$ and $\mathrm{Mb} \mathrm{CO}$ binding and pharmacokinetics}

Table 1 lists the important quantitative $\mathrm{CO}$ parameters that will be used in this review. The aqueous solubility $(\alpha)$ allows one to convert from the partial pressure in the gas phase $(\mathrm{P})$ to the molar free concentration (c) in the solution with which the gas is in equilibrium:

$$
c=\alpha P
$$

The biologically important concentration of $\mathrm{CO}$ that drives reactions, receptor binding, or diffusion is $c$, the free (unbound) concentration of $\mathrm{CO}$ that is dissolved in the tissue fluid or plasma. The free concentration of $\mathrm{CO}$ is not directly measured, but rather the $\mathrm{P}_{\mathrm{CO}}$ is determined and is then used to calculate the free concentration via use of the solubility coefficient. Using an $\alpha=1.1 \mu \mathrm{mol} / \mathrm{L} / \mathrm{mmHg}$ (Table 1), a $1 \mu \mathrm{M}$ free solution $\mathrm{CO}$ concentration corresponds to a $0.9 \mathrm{mmHg}$ (or 1,188 parts per million [ppm]) partial gas pressure.

The concept that $\mathrm{CO}$ serves a signaling function is largely derived from the observation that tissue function is altered by in vitro or in vivo exposure to $\mathrm{CO}$. Such alterations could reflect a specific messenger function or a non-specific toxicity of this gas. To differentiate between these two possibilities, it 
is necessary to know the concentration of free $\mathrm{CO}$ that exists in tissue at baseline and following $\mathrm{CO}$ administration, values that are dependent on $\mathrm{CO}-\mathrm{O}_{2}$ binding competition in $\mathrm{Hb}$ and tissue heme proteins. Classical $\mathrm{CO}$ toxicity is mediated via binding to $\mathrm{Hb}$, with a resultant decreased $\mathrm{O}_{2}$ delivery to the tissues. This binding is quantitated by the fraction of $\mathrm{CO}$-bound $\mathrm{Hb}$ ( $\mathrm{HbCO})$. Since standard whole-animal experimental $\mathrm{CO}$ administration is usually achieved via a short-period CO inhalation, it is important to understand the time dependence of the change in $\mathrm{HbCO}$ during and following this $\mathrm{CO}$ exposure, and its effect on tissue $\mathrm{O}_{2}$ delivery. In addition, since $\mathrm{CO}$ and $\mathrm{O}_{2}$ compete for $\mathrm{COX}$ binding, a decreased tissue oxygen partial pressure $\left(\mathrm{P}_{\mathrm{O}_{2}}\right)$ results in an increased $\mathrm{CO}-\mathrm{COX}$ binding. The following analysis presents a detailed description of the complex non-linear relationship between $\mathrm{HbCO}$ versus $\mathrm{P}_{\mathrm{CO}}$ and $\mathrm{P}_{\mathrm{O}_{2}}$. When analyzing this relationship, it is crucial to recognize that $\mathrm{CO}$ and $\mathrm{O}_{2}$ are competing for the same heme binding sites.

For $\mathrm{Mb}$, where there is just one binding site and no significant cooperative binding (Hill coefficient $=1$ ), the equation for the fraction $\mathrm{CO}(\mathrm{MbCO})$ and $\mathrm{O}_{2}\left(\mathrm{MbO}_{2}\right)$ bound has the following standard competitive binding form: ${ }^{14}$

$$
\begin{aligned}
M b C O & =\frac{P_{C O}}{P_{O_{2}} / \mathrm{M}_{M b}+P_{C O}+\left(P_{50}\right)_{C O}} \\
M b O_{2} & =\frac{\left(p O_{2} / \mathrm{M}_{M b}\right)}{P_{O_{2}} / \mathrm{M}_{M b}+P_{C O}+\left(P_{50}\right)_{C O}}
\end{aligned}
$$

The binding is characterized by the two parameters, $\left(\mathrm{P}_{50}\right)_{\mathrm{CO}}$, the partial pressure for $50 \%$ binding of $\mathrm{CO}$ in the absence of $\mathrm{O}_{2}$, and $\mathrm{M}_{\mathrm{Mb}}$, which is the affinity of $\mathrm{CO}$ relative to $\mathrm{O}_{2}$ :

$$
M_{M b}=\frac{M b C O / M b O_{2}}{P_{C O} / P_{O_{2}}}
$$

The corresponding $\left(\mathrm{P}_{50}\right)_{\mathrm{O}_{2}}$ is $\mathrm{M}_{\mathrm{Mb}} \times\left(\mathrm{P}_{50}\right)_{\mathrm{CO}}$. In the following calculations, values of $\left(\mathrm{P}_{50}\right)_{\mathrm{CO}}=0.07 \mathrm{mmHg}$ and $\mathrm{M}_{\mathrm{Mb}}=39$ will be used (Table 1). ${ }^{14}$

For $\mathrm{Hb}$, where there is cooperative binding between the four heme sites, the fraction of $\mathrm{CO}(\mathrm{HbCO})$ and $\mathrm{O}_{2}\left(\mathrm{HbO}_{2}\right)$ bound can be approximately described by a variant of the Adair equation: ${ }^{14}$

$$
\begin{aligned}
& H b C O=\left(M_{H b} P_{C O} / z\right) \frac{A_{1} z+2 A_{2} z^{2}+3 A_{3} z^{3}+4 A_{4} z^{4}}{4\left[1+A_{1} z+A_{2} z^{2}+A_{3} z^{3}+A_{4} z^{4}\right]} \\
& H_{b} O_{2}=\left(P_{O_{2}} / z\right) \frac{A_{1} z+2 A_{2} z^{2}+3 A_{3} z^{3}+4 A_{4} z^{4}}{4\left[1+A_{1} z+A_{2} z^{2}+A_{3} z^{3}+A_{4} z^{4}\right]}
\end{aligned}
$$

where $\mathrm{z}=\mathrm{P}_{\mathrm{O}_{2}}+\mathrm{M}_{\mathrm{Hb}} \mathrm{P}_{\mathrm{CO}}$ and $\mathrm{M}_{\mathrm{Hb}}$ is the affinity of the heme subunit for $\mathrm{CO}$ relative to $\mathrm{O}_{2}$ and is defined by the Haldane relationship:

$$
M_{\mathrm{Hb}}=\frac{\mathrm{HbCO} / \mathrm{HbO}_{2}}{P_{\mathrm{CO}} / P_{\mathrm{O}_{2}}}
$$

This equation assumes that $\mathrm{CO}$ and $\mathrm{O}_{2}$ compete for each of the four heme sites with the same relative affinity for $\mathrm{M}_{\mathrm{Hb}}$ and that the cooperativity of binding is identical for $\mathrm{O}_{2}$ and $\mathrm{CO}$. The following set of parameters will be used here: ${ }^{15,16}$ $\mathrm{M}_{\mathrm{Hb}}=220 ; \mathrm{A}_{1}=0.0218 ; \mathrm{A}_{2}=0.000912 ; \mathrm{A}_{3}=3.75 \times 10^{-6}$; and $\mathrm{A}_{4}=2.47 \times 10^{-6}$.

Although Equation 5 is not precise because the cooperativity of $\mathrm{CO}$ differs slightly from that of $\mathrm{O}_{2}$ and the Adair equation is not exact, even for pure oxygen, ${ }^{15,16}$ it is a quite good approximation and will be used in the following calculations to illustrate the physiologically important interactions between $\mathrm{P}_{\mathrm{O}_{2}}, \mathrm{P}_{\mathrm{CO}}$, and the fraction of $\mathrm{Hb}$ that is occupied by $\mathrm{CO}(\mathrm{HbCO})$ in human blood. Figure 1 shows a plot of Equations 3 and 5 for $\mathrm{HbCO}$ (red lines) and $\mathrm{MbCO}$ (black lines) as a function of the $\mathrm{P}_{\mathrm{CO}}$ for $\mathrm{P}_{\mathrm{O}_{2}}$ value of 95 (solid line), 50 (long-dashed line), and $20 \mathrm{mmHg}$ (dotdashed line). The competition between $\mathrm{CO}$ and $\mathrm{O}_{2}$ implies

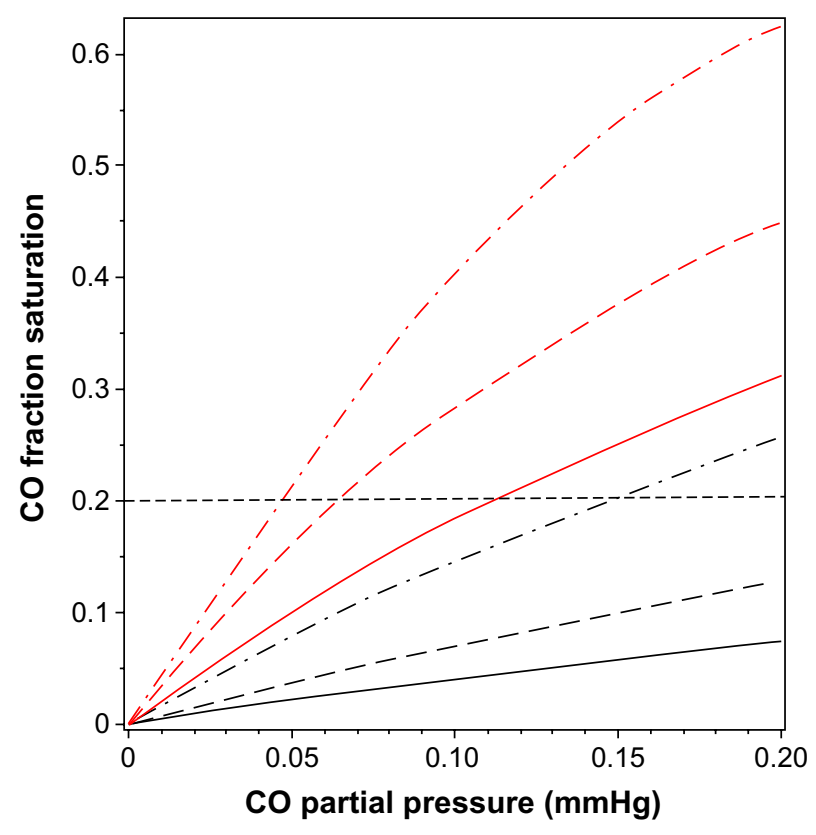

Figure I Plot of fraction of hemoglobin (red lines) and myoglobin (black lines) that is occupied by $\mathrm{CO}$ as a function of $\mathrm{P}_{\text {co }}$, for a fixed $\mathrm{P}_{\mathrm{O}_{2}}$ of $95 \mathrm{mmHg}$ (solid lines), $50 \mathrm{mmHg}$ (long-dashed lines), and $20 \mathrm{mmHg}$ (dot-dashed lines). The black, horizontal dashed line indicates that for a fixed $\mathrm{HbCO}$ fraction of 0.2 , the equilibrium $\mathrm{P}_{c O}$ is $0.112 \mathrm{mmHg}$ for a $\mathrm{P}_{\mathrm{O}_{2}}$ of $95 \mathrm{mmHg}$, and decreases to a $\mathrm{P}_{\mathrm{cO}}$ of $0.047 \mathrm{mmHg}$ when the $\mathrm{P}_{\mathrm{O}_{2}}$ decreases to $20 \mathrm{mmHg}$.

Abbreviations: $\mathrm{P}_{\mathrm{O}_{2}}, \mathrm{O}_{2}$ partial pressure; $\mathrm{Hb}$, hemoglobin; $\mathrm{HbCO}$, CO-bound $\mathrm{Hb}$; $\mathrm{P}_{\mathrm{CO}}, \mathrm{CO}$ partial pressure. 
that, in the steady state, the $\mathrm{P}_{\mathrm{CO}}$ in the capillary (eg, tissue) is significantly less than the arterial $\mathrm{P}_{\mathrm{CO}}$ because the lower capillary $\mathrm{P}_{\mathrm{O}_{2}}$ leads to a greater $\mathrm{HbCO}$ affinity. Since the body is a closed system with most of the $\mathrm{CO}$ bound to $\mathrm{Hb}$ (see discussion of equation 10 ), the value of $\mathrm{HbCO}$ remains relatively constant as the blood moves from the artery to the capillaries. As illustrated in Figure 1, for a fixed $\mathrm{HbCO}$ of 0.2 (horizontal dashed line), as the $\mathrm{P}_{\mathrm{O}_{2}}$ decreases from 95 (artery) to 20 (vein) $\mathrm{mmHg}$, the $\mathrm{P}_{\mathrm{CO}}$ falls from 0.112 to $0.047 \mathrm{mmHg}$.

Figure $2 \mathrm{~A}$ shows the $\mathrm{O}_{2} \mathrm{Hb}$ saturation $\left(\mathrm{HbO}_{2}\right)$ as a function of $\mathrm{P}_{\mathrm{O}_{2}}$ in the presence of a $\mathrm{P}_{\mathrm{CO}}$ of $0,0.1,0.2$, and $0.5 \mathrm{mmHg}$, as determined by Equation 5. The presence of $\mathrm{CO}$ not only reduces the value of $\mathrm{HbO}_{2}, \mathrm{CO}$ also changes the shape of the $\mathrm{O}_{2}$ dissociation curve, shifting it to the left. This shift is seen more clearly in Figure 2B, where the $\mathrm{O}_{2}$ saturation relative to the maximal $\mathrm{O}_{2}$ saturation at $\mathrm{P}_{\mathrm{O}_{2}}=100 \mathrm{mmHg}$ is plotted, instead of the absolute saturation, which is plotted in Figure $2 \mathrm{~A}$. The $\mathrm{P}_{\mathrm{O}_{2}}$ for $50 \%$ of maximum binding falls from a normal value of $26 \mathrm{mmHg}$ in the absence of $\mathrm{CO}$ to $12.6 \mathrm{mmHg}$ for a $\mathrm{P}_{\mathrm{CO}}$ of $0.5 \mathrm{mmHg}$. Thus, $\mathrm{CO}$ produces tissue anoxia not simply by displacing $\mathrm{O}_{2}$ from $\mathrm{Hb}$ but also because the tissue $\mathrm{O}_{2}$ must fall to lower values in order to release the $\mathrm{O}_{2}$ that has not been displaced.

A critical concept central to this review is that the blood, which serves as a CO sink for all tissues, normally maintains a very low $\mathrm{P}_{\mathrm{CO}}$. Venous blood $\mathrm{P}_{\mathrm{CO}}$ in humans can be estimated from the normal venous $\mathrm{HbCO}$ value of $0.8 \%$ and by applying
Equation 6 to venous blood $\left(\mathrm{P}_{\mathrm{O}_{2}}=40 \mathrm{mmHg} ; \mathrm{HbO}_{2}=0.75\right.$ $\mathrm{mmHg} ; \mathrm{M}_{\mathrm{Hb}}=220 \mathrm{mmHg}$ ):

$$
P_{C O}=\frac{P_{\mathrm{O}_{2}} \mathrm{HbCO}}{M_{\mathrm{Hb}} \mathrm{HbO}_{2}} \approx \frac{40 \times 0.008}{220 \times 0.74}=0.0019 \mathrm{mmHg}
$$

Probably the best direct experimental measurement of human blood $\mathrm{P}_{\mathrm{CO}}$ is the breath holding end alveolar $\mathrm{P}_{\mathrm{CO}}$ value of $2.44 \mathrm{ppm}(0.0018 \mathrm{mmHg})$ obtained by Furne et al. ${ }^{17}$ This value should be close to equilibrium with the average pulmonary capillary blood. These values are summarized in Table 1 .

The classical approach to administering $\mathrm{CO}$ in experimental studies is via inspired air. To extrapolate from alterations in cell function observed in such studies to potential signaling mechanisms induced by endogenous $\mathrm{CO}$ production, it is necessary to know the cellular $\mathrm{P}_{\mathrm{CO}}$ that results from $\mathrm{CO}$ inhalation. Although the time-dependent pharmacokinetics are complicated, with a $\mathrm{CO}$ pulmonary diffusion limitation and varying rates of distribution to the different organs and tissues, a surprisingly simple expression derived by Coburn et $\mathrm{al}^{18}$ provides a good approximation. The long-time steady state $(\mathrm{HbCO})_{\text {ss }}$ can be obtained by application of the Haldane relation (Equation 6) to the pulmonary capillary blood:

$$
(\mathrm{HbCO})_{s s}=\mathrm{M}_{\mathrm{Hb}} \mathrm{HbO}_{2} \mathrm{I}_{\mathrm{CO}} / \mathrm{A}_{\mathrm{O}_{2}}
$$

where $\mathrm{I}_{\mathrm{CO}}$ is the inspired alveolar $\mathrm{P}_{\mathrm{CO}}, \mathrm{A}_{\mathrm{O}_{2}}$ is the average pulmonary capillary $\mathrm{P}_{\mathrm{O}_{2}}$, and $\mathrm{HbO}_{2}$ is the average pulmonary capillary $\mathrm{HbO}_{2}$ saturation. Using the approximate relations
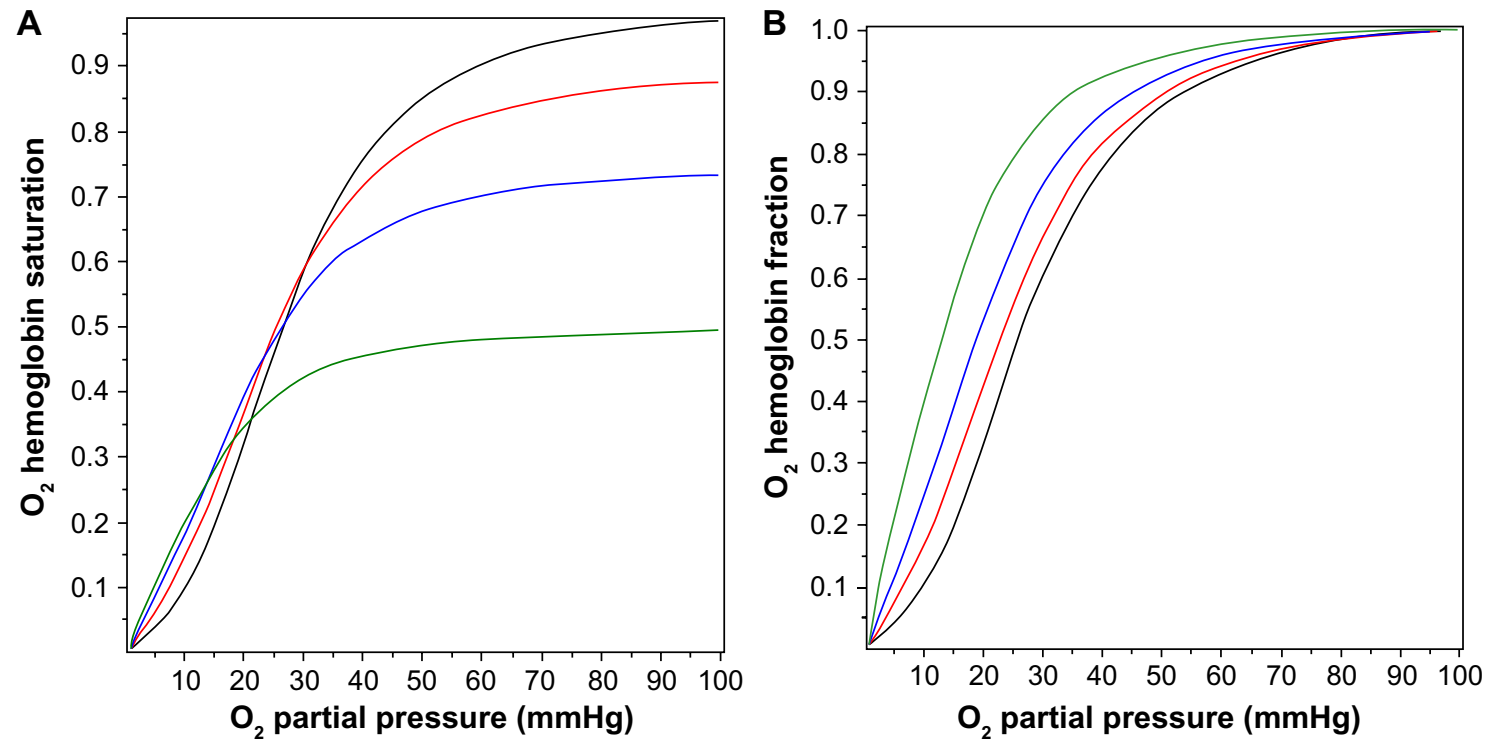

Figure 2 Fractional saturation of hemoglobin occupied by $\mathrm{O}_{2}$ as a function of the $\mathrm{P}_{\mathrm{O}_{2}}$ for $\mathrm{P}_{\text {co }}$ fixed at $0 \mathrm{mmHg}$ (black line), $0.1 \mathrm{mmHg}$ (red line), $0.2 \mathrm{mmHg}$ (blue line), and $0.5 \mathrm{mmHg}$ (green line). In (A), the absolute $\mathrm{O}_{2}$ saturation of the total hemoglobin is plotted, while in $(\mathbf{B})$, the fraction saturated with $\mathrm{O}_{2}$ relative to the maximum $\mathrm{O}_{2}$ saturation at $\mathrm{P}_{\mathrm{O}_{2}}=100 \mathrm{mmHg}$ is plotted.

Abbreviations: $\mathrm{P}_{\mathrm{O}_{2}}, \mathrm{O}_{2}$ partial pressure; $\mathrm{P}_{\mathrm{CO}}, \mathrm{CO}$ partial pressure. 
that $\mathrm{HbCO}+\mathrm{HbO} \approx 1$ and $\mathrm{A}_{\mathrm{O}_{2}} \approx 100 \mathrm{mmHg}$ for breathing room air:

$$
(H b C O)_{s s} \approx M_{H b} I_{C O} /\left(100+M_{H b} I_{C O}\right)
$$

That is, the steady state $\mathrm{HbCO}$ for an arbitrary value of inspired alveolar $\mathrm{P}_{\mathrm{CO}}$ (also known as $\mathrm{I}_{\mathrm{CO}}$ ) can be estimated simply from the value of $\mathrm{M}_{\mathrm{Hb}}(\approx 220)$. This represents the contribution from exogenous inspired $\mathrm{CO}$. The total blood $\mathrm{HbCO}$ is the sum of this term plus the baseline endogenous $\mathrm{HbCO}$. The time-dependent change in blood $\mathrm{HbCO}$ in response to inhaled $\mathrm{CO}$ (neglecting the endogenous $\mathrm{CO}$ production) is well approximated by a single exponential, based on the assumption that the total body $\mathrm{CO}$ volume of distribution can be represented by a well-mixed blood volume $\left(\mathrm{V}_{\mathrm{b}}\right){ }^{18}$

$$
\begin{aligned}
& H b C O=(H b C O)_{s s}\left(1-e^{-t / T}\right) \\
& T=M_{H b} V_{b}\left[H b O_{2}\right]\left(\frac{1}{D_{L}}+\frac{P_{A t m}}{\dot{V}_{A}}\right) / A_{O_{2}}
\end{aligned}
$$

where $\mathrm{D}_{\mathrm{L}}$ is the $\mathrm{CO}$ lung diffusivity, $\mathrm{P}_{\mathrm{Atm}}$ is the atmospheric pressure corrected for vapor pressure of water $(713 \mathrm{mmHg})$, $\dot{V}_{A}$ is alveolar ventilation, $\mathrm{V}_{\mathrm{b}}$ is the effective blood volume, and $\left[\mathrm{HbO}_{2}\right]$ is the average pulmonary capillary blood $\mathrm{O}_{2}$ concentration in $\mathrm{mL} \mathrm{STP} / \mathrm{mL}$ blood. Equations 9 and 10 provide good fits to the time-dependent experimental data in humans for inhaled $\mathrm{CO}$ ranging from $25 \mathrm{ppm}(0.019 \mathrm{mmHg})$ to $500 \mathrm{ppm}(0.38 \mathrm{mmHg})$, assuming that $\left[\mathrm{HbO}_{2}\right]=0.2$ and $\mathrm{A}_{\mathrm{O}_{2}}=100 \mathrm{mmHg}$. ${ }^{19}$ The major simplifying assumption of this model is that the total body $\mathrm{CO}$ volume of distribution can be represented by an "equivalent" $\mathrm{V}_{\mathrm{b}}$. This explanation is a good approximation, because the vast majority of the total body $\mathrm{CO}$ binding is provided by $\mathrm{Hb}$, eg, in humans there is roughly $800 \mathrm{~g} \mathrm{Hb}$, versus only $34.7 \mathrm{~g} \mathrm{Mb}$ and much lower concentrations of other cellular hemes (eg, $0.78 \mathrm{~g}$ $\mathrm{COX}) .{ }^{20}$ Since $\mathrm{Hb}$ has the highest $\mathrm{CO}$ affinity (Table 1 and Figure 1), at least $94 \%$ of the total body $\mathrm{CO}$ is in the blood. A second assumption is that $\left[\mathrm{HbO}_{2}\right]$ is constant during the entire $\mathrm{CO}$ inhalation time course. This is clearly incorrect if the $\mathrm{CO}$ concentration is high enough to saturate a significant fraction of $\mathrm{Hb}$. Bruce and Bruce ${ }^{21}$ have described a much more detailed, multi-compartment, physiologically based pharmacokinetic model that, presumably, is more accurate. However, the experimental data are probably not good enough to distinguish them from the simple model described above.

From Equation 10, the time constant $\mathrm{T}$ for humans $\left(\mathrm{D}_{\mathrm{L}} \approx 30 \mathrm{~mL} / \mathrm{min} / \mathrm{mmHg} ; \mathrm{V}_{\mathrm{b}} \approx 5.5 \mathrm{~L} ;\right.$ and $\left.\dot{V}_{A} \approx 6 \mathrm{~L} / \mathrm{min}\right)$ is about
360 minutes, which is in good agreement with experimental data. ${ }^{19}$ It is of interest to see how this time constant scales for different animals, in particular the rat and mouse, which are the commonly used experimental models. Neglecting the $1 / D_{L}$ term (assume lung diffusion is infinite), which is only $30 \%$ of the $\mathrm{P}_{\mathrm{Atm}} / \dot{V}_{A}$ term, the $\mathrm{T}$ for animal $\mathrm{x}$ relative to the human is given by:

$$
T_{x} / T_{\text {human }}=\frac{\left(V_{b} / \dot{V}_{A}\right)_{x}}{\left(V_{b} / \dot{V}_{A}\right)_{\text {human }}}
$$

Using values for the rat $\left(\mathrm{V}_{\mathrm{b}}=0.07 \mathrm{~g} / \mathrm{g}, 22\right.$ and $\dot{V}_{A}=0.39 \mathrm{~mL} /$ $\left.\mathrm{min} / \mathrm{g}^{23}\right)$ and the mouse $\left(\mathrm{V}_{\mathrm{b}}=0.09 \mathrm{~g} / \mathrm{g},{ }^{22}\right.$ and $\dot{V}_{A}=0.81$ $\mathrm{mL} / \mathrm{min} / \mathrm{g}^{23}$ ), and (assuming dead space is $33 \%$ of tidal volume), the $\mathrm{CO}$ time constant is 70 minutes and 43 minutes for the rat and mouse, respectively. This value for the rat is in rough agreement with direct experimental measurements. ${ }^{24}$ A common experimental model is to expose mice to $250 \mathrm{ppm}$ $\mathrm{CO}$ for a period of 1 hour, and from the above estimate of T, at the end of the hour, mice should have reached $75 \%$ of their steady state value.

\section{COX binding and ROS formation}

Although there are hundreds of heme proteins ${ }^{25}$ that could potentially be modified by $\mathrm{CO}$, the only major proteins with well-characterized, relatively high affinity $\mathrm{CO}$ binding are $\mathrm{Hb}, \mathrm{Mb}$, cytochrome $\mathrm{P}_{450}$, and $\mathrm{COX}^{26}$ (refer to the "Specific $\mathrm{CO}$ sensors or receptors" section for a further discussion of other possible minor $\mathrm{CO}$ binding proteins). Of the four complexes in the electron transport chain, three of which contain heme proteins, only complex IV (otherwise known as COX) is significantly inhibited by low levels of $\mathrm{CO}^{27}$ Historically, COX has been the major focus of studies of cellular CO toxicity. The quantitative aspects of the binding of $\mathrm{CO}$ to $\mathrm{COX}$ are of particular importance because this binding produces a non-specific asphyxiation of all cells. When investigating the actions of $\mathrm{CO}$, it is essential to distinguish this general COX inhibition from the more directed, specific $\mathrm{CO}$ signaling mechanisms that are discussed in the "Specific CO sensors or receptors" section. This "toxicity" has recently taken on special importance because of a number of reports of alterations of physiological function induced by surprisingly low doses of CO (eg, 250 ppm for 1 hour, see Discussion section). These effects have been attributed to the formation of ROS produced by CO inhibition of COX, the last step in the electron transport chain, ${ }^{28}$ as opposed to an effect attributable to a conventional messenger function in which $\mathrm{CO}$ binds to a specific $\mathrm{CO}$ receptor. 
As was the case for $\mathrm{Hb}$ and $\mathrm{Mb}, \mathrm{O}_{2}$ and $\mathrm{CO}$ are competing for the same binding site in COX. Using purified COX, Petersen ${ }^{29}$ showed that $\mathrm{CO}$ behaves as a classical competitive enzyme inhibitor of $\mathrm{O}_{2}$, with the activity $(\mathrm{V})$ characterized by the $\mathrm{O}_{2} \mathrm{~K}_{\mathrm{m}}$ and the $\mathrm{CO}$ inhibition constant $\left(\mathrm{K}_{\mathrm{i}}\right)$ :

$$
V=\frac{V_{m} P_{O_{2}}}{K_{m}\left(1+P_{C O} / K_{i}\right)+P_{O_{2}}}=\frac{V_{m} P_{O_{2}}}{M_{C O X} P_{C O}+P_{O_{2}}+\left(P_{50}\right)_{O_{2}}}
$$

The second equality is in the same form used to describe $\mathrm{CO}$ binding to $\mathrm{Mb}$ (Equation 3), with $\left(\mathrm{P}_{50}\right)_{\mathrm{O}_{2}}=\mathrm{K}_{\mathrm{m}}$ and $\mathrm{M}_{\mathrm{COX}}=$ $\mathrm{K}_{\mathrm{m}} / \mathrm{K}_{\mathrm{i}}$. The fraction of COX inhibited by the addition of a given $\mathrm{P}_{\mathrm{CO}}$ to a medium with a fixed $\mathrm{P}_{\mathrm{O}_{2}}$ is described by an equation similar to Equation 3, with $\left(\mathrm{P}_{50}\right)_{\mathrm{CO}}$ equal to the $\mathrm{K}_{\mathrm{i}}$ of $\mathrm{CO}$ :

$$
\operatorname{Cox} C O=\frac{P_{C O}}{P_{C O}+K_{i}+\frac{P_{O_{2}}}{M_{C O X}}}
$$

It can be seen from Equation 13 that the fractional COX inhibition by $\mathrm{CO}$ is critically dependent on the $\mathrm{P}_{\mathrm{O}_{2}}$ at the COX binding site. At high $\mathrm{P}_{\mathrm{CO}}$ and $\mathrm{P}_{\mathrm{O}_{2}}$, the $\mathrm{K}_{\mathrm{i}}$ term in the denominator is negligible, and the fraction $\mathrm{CO}$ inhibition is characterized by $\mathrm{M}_{\mathrm{COX}}$.

The $\mathrm{CO} \mathrm{K}_{\mathrm{i}}$ of COX is about $0.3 \mu \mathrm{M}$ (or $0.27 \mathrm{mmHg}$ ). ${ }^{29,30}$ Yoshikawa et $\mathrm{al}^{31}$ directly measured $\mathrm{CO}$ binding to purified anaerobic COX using infrared spectroscopy and found a $\mathrm{K}_{\mathrm{d}}$ of $0.3 \mu \mathrm{M}$, identical to the $\mathrm{CO} \mathrm{K}_{\mathrm{i}}$, as is predicted for a simple competitive inhibitor. Wohlrab and Ogunmola ${ }^{32}$ found a similar $\mathrm{K}_{\mathrm{d}}$ of $0.46 \mu \mathrm{M}$ (or $0.42 \mathrm{mmHg}$ ) for $\mathrm{CO}$ binding to $\mathrm{COX}$ in intact liver mitochondria. The corresponding $\mathrm{K}_{\mathrm{m}}$ (or $\mathrm{K}_{\mathrm{d}}$ ) of mitochondria for $\mathrm{O}_{2}$ is less certain and varies with the metabolic state, but is probably in the range of 0.1 to $0.8 \mu \mathrm{M}^{33,34}$ Petersen $^{29}$ found a $\mathrm{K}_{\mathrm{m}}$ for $\mathrm{O}_{2}$ of $0.75 \mu \mathrm{M}$ using the same purified COX enzyme assay used to determine the $\mathrm{K}_{\mathrm{i}}$ of CO. Using this value of $\mathrm{K}_{\mathrm{m}}$, the value of $\mathrm{M}_{\mathrm{COX}}$ should be $0.75 / 0.3$ or 2.5 . These values of $\mathrm{K}_{\mathrm{m}}, \mathrm{K}_{\mathrm{i}}$, and $\mathrm{M}_{\mathrm{COX}}$ will be used throughout this report.

This apparently high $\mathrm{CO}-\mathrm{COX}$ affinity of $0.3 \mu \mathrm{M}$ (or $0.027 \mathrm{mmHg}$; or $35 \mathrm{ppm}$ ) does not, at first, seem consistent with the classic observation that $\mathrm{CO}$ has relatively minor effects on the rate of $\mathrm{O}_{2}$ consumption of whole organs. . $^{35,36}$ For example, Glabe et al, ${ }^{36}$ using isolated saline perfused rat hearts, measured the maximum $\mathrm{O}_{2}$ consumption and cellular adenosine triphosphate (ATP) and phosphocreatine using proton nuclear magnetic resonance and found no significant change in any of these variables, even for a saline $\mathrm{P}_{C O}$ as high as a $100 \mathrm{mmHg}$ (with a saline $\mathrm{P}_{\mathrm{O}_{2}}$ of $540 \mathrm{mmHg}$ ). Assuming that the $\mathrm{P}_{\mathrm{O}_{2}}$ at the $\mathrm{COX}$ binding site is $100 \mathrm{mmHg}$ for this perfusion $\mathrm{P}_{\mathrm{O}_{2}}$ of $540 \mathrm{mmHg}$, and using Equation 13, one would predict that a $\mathrm{P}_{\mathrm{CO}}$ of $100 \mathrm{mmHg}$ should produce about a $70 \%$ COX inhibition. However, this $70 \%$ COX inhibition would not be expected to have a major effect on organ oxidative metabolism because of the "branching" and "cushioning" phenomena originally described by Chance et al. ${ }^{37}$ Even though most of the COX is inhibited by $\mathrm{CO}$, the remaining uninhibited $\mathrm{COX}$ can branch out and oxidize the neighboring CO-inhibited COX chains, leading to relatively normal ATP synthesis. ${ }^{33,37,38}$

A major focus of recent $\mathrm{CO}$ signaling research is the formation of ROS secondary to COX inhibition by $\mathrm{CO}$. Zuckerbraun et $\mathrm{al}^{28}$ have shown that relatively low concentrations of CO (1 hour exposure to $250 \mathrm{ppm}$, or $0.19 \mathrm{mmHg}$ ) in a cell culture system produced a large increase in ROS formation, seemingly due to $\mathrm{CO}$ inhibition of COX. There is no evidence that other heme-containing enzymes that assist in the removal of ROS (eg, superoxide dismutase [SOD] or catalase) are inhibited by these CO concentrations. Normally, there is a small basal leak of ROS from the respiratory transport chain complexes I-III that feed into COX (complex IV), and this leak is markedly increased when COX is partially inhibited, presumably because of a blockade at the terminal step accompanying a buildup in the electron driving pressure. ${ }^{39}$ Nitric oxide (NO) also inhibits COX (in a somewhat different manner), but this inhibition is not thought to be a major NO signaling pathway, because $\mathrm{NO}-\mathrm{COX}$ affinity is 50 -fold less than the affinity of NO for guanylate cyclase. ${ }^{38}$

Although ROS production historically has been regarded as a pathologic process, it recently has been proposed that ROS can serve as an important signaling mechanism. ${ }^{40,41}$ If so, CO-induced COX inhibition should be considered to be a physiological process, with the resultant ROS formation being the best validated $\mathrm{CO}$ second messenger system. As discussed, large increases in ROS generation can occur with minimal changes in overall respiration, thus providing the putative messenger in the absence of cell asphyxiation. The "specificity" of this ROS release presumably would be determined by the cellular systems that are modified by increased ROS exposure. ROS release is remarkably sensitive to low $\mathrm{CO}$ exposures. Thom et $\mathrm{al}^{42}$ measured rates of cell death and the cellular levels of antioxidant enzymes such as SOD as a function of time after short exposures to $\mathrm{CO}$ in a cell culture system. Just a 1-hour exposure to $100 \mathrm{ppm} \mathrm{CO}$ (or $0.08 \mathrm{mmHg}$ ) resulted in a significantly increased ROS and an increase in cell death at 18 days. A 1-hour exposure to 
10 ppm CO did not increase death rates, but was associated with a 3-fold increase in SOD levels, which were, presumably, a surrogate signal of increased ROS formation. This $10 \mathrm{ppm} \mathrm{CO}(0.008 \mathrm{mmHg})$ is only $4 \times$ the normal blood level and is commonly observed in smokers. ${ }^{43}$

The quantitative relationship between COX binding and ROS release is poorly understood. Not commonly considered is that competition between $\mathrm{O}_{2}$ and $\mathrm{CO}$ for $\mathrm{COX}$ (Equation 13) makes this relationship strongly dependent on the $\mathrm{P}_{\mathrm{O}_{2}}$ at the COX binding site. In the typical cell culture experiments in petri plates $^{42}$ or 96-well tissue culture plates ${ }^{28}$, the effective cell $\mathrm{P}_{\mathrm{O}_{2}}$ is poorly characterized. Peng and Palsson ${ }^{44}$ have shown that these tissue cultures at high cell density may become oxygen limited, ie, the $\mathrm{P}_{\mathrm{O}_{2}}$ at the $\mathrm{COX}$ site may be close to $0 \mathrm{mmHg}$. Using the $\mathrm{CO} \mathrm{K}_{\mathrm{i}}$ of $0.27 \mathrm{mmHg}$ and Equation 13, the maximum possible $\mathrm{COX}-\mathrm{CO}$ (ie, within the limit as $\mathrm{P}_{\mathrm{O}_{2}}$ approaches $0 \mathrm{mmHg})$ is $2.7 \%$ for the $10 \mathrm{ppm} \mathrm{CO}(0.0076$ $\mathrm{mmHg}$ ) in the Thom et $\mathrm{al}^{42}$ experiment and $41 \%$ for the 250 ppm CO in the Zuckerbraun et $\mathrm{al}^{28}$ experiment. This last prediction is in good agreement with the 50\% COX inhibition directly measured by Zuckerbraun et $\mathrm{al}^{28}$ at $250 \mathrm{ppm} \mathrm{CO}$. Despite this 50\% COX inhibition, Zuckerbraun et $\mathrm{al}^{28}$ found that there was no significant change in cellular ATP, consistent with the classic "branching" effect Chance et al ${ }^{37}$ described. If this quantitative analysis is correct, it indicates that very small fractional CO-COX binding (eg, 2.7\%) can have significant physiological effects, presumably by producing a relatively large change in the rate of ROS production. It also implies that, specifically, it is important to consider the competing $\mathrm{O}_{2}$ concentration when evaluating $\mathrm{CO}$ actions. For example, Zhang et $\mathrm{al}^{45}$ have shown that $\mathrm{CO}$ concentrations of only 15 ppm have a major anti-apoptotic effect on cultured cells that have undergone an anoxia-reoxygenation protocol, consistent with the prediction that $\mathrm{CO}-\mathrm{COX}$ inhibition will be maximized in anoxic conditions.

\section{Specific CO sensors or receptors}

Initially, a second messenger role for $\mathrm{CO}$ was based on the concept that this gas interacted with specific receptors and thus might have a variety of specific actions (in contrast to the non-specific activity that seemingly would result from COX inhibition). However, there are surprisingly little data with regard to the identity or structure of such $\mathrm{CO}$ receptors. Initial enthusiasm for a messenger role for $\mathrm{CO}$ was based on the demonstration that exposure to this gas activated soluble guanylate cyclase ( $\mathrm{sGC}$ ), a heme-containing protein, resulting in production of cyclic guanosine monophosphate (analogous to the action of NO). ${ }^{46,47}$ This concept was based on the demonstration of the activation of whole cell $\mathrm{K}^{+}$currents in corneal epithelial cells and jejunal smooth muscle, when equilibrated with a very high $\mathrm{P}_{\mathrm{CO}}$ of $7.6 \mathrm{mmHg}{ }^{47,48}$ Subsequent observations showing that $\mathrm{CO}$ produced only a maximum 4.4-fold activation of purified sGC compared to the 130 -fold activation with $\mathrm{NO}^{48}$ and that the sGC-CO affinity was low (with a $\mathrm{K}_{\mathrm{m}}$ of about $10 \mu \mathrm{M}^{49}$ ) raised serious doubts about sGC as a mediator of $\mathrm{CO}$ action. ${ }^{50}$ This sGC example is illustrative of a major limitation of many proposed specific $\mathrm{CO}$ second messenger actions. The observed responses to $\mathrm{CO}$ could simply be a non-specific reaction to the tissue asphyxiation that results from the massively superphysiological $\mathrm{CO}$ concentrations employed (eg, $7.6 \mathrm{mmHg}$ in the sGC example, which is $4,000 \times$ the normal plasma $\mathrm{CO}$ ).

The classical second messenger reacts with a receptor that provides specificity to the signaling. Given the extensive literature ascribing a messenger function for $\mathrm{CO}$, there is a surprising paucity of data identifying the $\mathrm{CO}$-specific receptors. The best understood $\mathrm{CO}$-mediated regulatory protein is the bacterial transcription factor $\mathrm{CO}$ oxidation activator (CooA), whose structure and function have been characterized in great detail. ${ }^{9,51}$ This protein is a CO-sensitive transcription activator in the bacterium Rhodospirillum rubrum, which can live on $\mathrm{CO}$ in anaerobic conditions. The activation of CooA is specific for $\mathrm{CO}$ and does not occur with $\mathrm{O}_{2}$, indicating that heme binding sites can be specific for $\mathrm{CO}$ sensing. The only reported homologous mammalian protein is involved in the neuronal circadian rhythm control system, ${ }^{52}$ and there is suggestive evidence that $\mathrm{CO}$ may have a role in the mammalian control of diurnal rhythm. ${ }^{53-55}$ The CooA affinity is relatively low, with a $\mathrm{P}_{50}$ of $2.2 \mu \mathrm{M}$ ( or $2 \mathrm{mmHg}$ ), ${ }^{56}$ about $1,000 \times$ higher than the normal blood CO (Table 1), and, as discussed in detail in the "Quantitative modeling of the steady state and time-dependent tissue CO in the presence of the blood sink" section, it is unlikely that normal tissue concentrations can reach this level.

The best characterized mammalian high-affinity $\mathrm{CO}$ receptors are the large conductance $\mathrm{Ca}^{++}$- and voltageactivated $\mathrm{K}^{+}$channels $\left(\mathrm{BK}_{\mathrm{Ca}}\right.$, also referred to as Slo1 or MaxiK), which are expressed in almost every cell type and are involved in vasodilation, oxygen sensing, neuronal excitability, transmitter release, and multiple other functions. ${ }^{57}$ The strongest evidence that $\mathrm{BK}_{\mathrm{Ca}}$ channels are $\mathrm{CO}$ receptors is that they can be activated by $1 \mu \mathrm{M} \mathrm{CO}$ in excised cell membrane patches that are free of COX, and presumably, other regulatory heme proteins. ${ }^{58,59}$ The main experimental focus has been on the involvement of this regulatory system in the control of smooth muscle vascular resistance, reviewed 
in great detail by Leffler et al. ${ }^{11}$ The most sensitive tissue described to date is the piglet pial vessels, with applied concentrations as low as $0.1 \mu \mathrm{M}(0.09 \mathrm{mmHg})$ producing a transient dilatation. ${ }^{60}$ Arterioles in adult pigs and in other mammals of all ages are appreciably less sensitive to $\mathrm{CO} .{ }^{61}$ For example, the rat tail artery model requires $\mathrm{CO}$ concentrations of about $10 \mu \mathrm{M}$ to produce a relaxation that is about $25 \%$ of the maximum CO-induced relaxation. ${ }^{62}$ The constitutive form of $\mathrm{HO}$ (HO-2) is expressed in high concentrations in central nervous system arterial endothelial cells and in their closely associated astrocytes, ${ }^{62}$ and the inducible form (HO-1) is highly expressed in peripheral vascular smooth muscle. ${ }^{63}$ The structural mechanism of the $\mathrm{CO}$ activation of $\mathrm{BK}_{\mathrm{Ca}}$ is not well understood, but seems to involve an interaction between $\mathrm{BK}_{\mathrm{Ca}}$ and cellular heme. ${ }^{58,64} \mathrm{~A}$ similar interaction of a calcium-activated potassium channel, heme, and $\mathrm{CO}$ has been described in a plant (pollen tube) system, ${ }^{65}$ suggesting that this CO regulatory mechanism may have an ancient lineage. Based on the above, it appears that tissue $\mathrm{HO}$ must raise the local tissue $\mathrm{CO}$ to at least $0.1 \mu \mathrm{M}$ to activate arteriolar $\mathrm{BK}_{\mathrm{Ca}}$. The physiology required for the generation of such a tissue concentration in the face of diffusion to blood is addressed quantitatively in the "Quantitative modeling of the steady state and time-dependent tissue $\mathrm{CO}$ in the presence of the blood sink" section.

Oxygen is a substrate for the $\mathrm{HO}$ reaction (Equation 1), and it has been suggested that $\mathrm{HO}$ is the carotid body $\mathrm{O}_{2}$ receptor, with high $\mathrm{O}_{2}$ increasing $\mathrm{HO}$ activity that then increases the rate of $\mathrm{CO}$ production, activating a $\mathrm{BK}_{\mathrm{Ca}}$ channel. ${ }^{66}$ One difficultly with this concept is that $\mathrm{HO}$ has a very high $\mathrm{O}_{2}$ affinity, with a $\mathrm{P}_{50}$ of 0.013 to $0.03 \mu \mathrm{M},{ }^{67}$ corresponding to a $\mathrm{P}_{\mathrm{O}_{2}}$ of 0.0094 to $0.022 \mathrm{mmHg}$ (using an $\mathrm{O}_{2}$ solubility of $1.38 \mu \mathrm{mol} / \mathrm{L} / \mathrm{mmHg}^{68}$ ), far below the $\mathrm{O}_{2}$ sensitivity range of the carotid body. A further complication is that HO knockout mice apparently have normal carotid body oxygen sensing. ${ }^{69}$

There is also suggestive evidence that the epithelial $\mathrm{Na}^{+}$ channel $(\mathrm{ENaC})$ is a high-affinity $\mathrm{CO}$ receptor. The $\mathrm{ENaC}$ activity of excised membrane patches from mouse kidney cortical collecting duct cells is stimulated by the addition of soluble heme at a concentration similar to that in the intact cell, with a $\mathrm{K}_{\mathrm{d}}$ of $23 \mathrm{nM}$, and this heme activation is increased by the addition of $\mathrm{CO}$ at concentrations as low as $0.1 \mu \mathrm{M} .{ }^{70}$ In addition, $\mathrm{O}_{2}$ is required to maintain the stimulatory effect of heme, suggesting that the $\mathrm{CO}$ production by membrane-associated $\mathrm{HO}$ is required for the heme-ENaC interaction and that this system might be another $\mathrm{O}_{2}$ sensor. $^{70}$ A potentially important clinical application of $\mathrm{CO}$ is based on the observation that inhalation of $\mathrm{CO}$ at concentrations of only $100 \mathrm{ppm}(0.076 \mathrm{mmHg} ; 0.084 \mu \mathrm{M})$ provides protection against hypoxic lung injury. ${ }^{71}$ It has been proposed that $\mathrm{ENaC}$ is the receptor responsible for this protection, ${ }^{72}$ and Althaus et $\mathrm{al}^{72}$ demonstrated that ventilation of isolated rabbit lungs with $250 \mathrm{ppm} \mathrm{CO}(0.19 \mu \mathrm{M})$ decreased alveolar sodium absorption and fluid clearance. Although they also showed that $\mathrm{CO}$ inhibited the apical amiloride-sensitive current (presumably ENaC), this might be an indirect result of inhibiting $\mathrm{COX}$, since it required very high concentrations $(100 \mu \mathrm{M})$ of a CO-releasing molecule, CORM-3. ${ }^{73}$ Extrapolation from such studies to a messenger role for endogenously produced $\mathrm{CO}$ requires demonstration that locally produced $\mathrm{CO}$ raises the tissue $\mathrm{CO}$ concentration to levels comparable to those achieved with exogenous administration of $\mathrm{CO}$.

Although $\mathrm{CO}$ has been proposed to be a regulator of many other ion channel types, including voltage-activated $\mathrm{K}^{+}$, L-type $\mathrm{Ca}^{++}$channels, ligand-gated $\mathrm{P} 2 \mathrm{X}$ receptors, and TREK1 P domain $\mathrm{K}^{+}$channels, the evidence that these channels are specific $\mathrm{CO}$ receptors is much weaker. ${ }^{73}$ One limitation of many of these studies is that the exact $\mathrm{CO}$ concentration used has not been well-characterized, because the $\mathrm{CO}$ was administered as various forms of $\mathrm{CO}$-releasing molecules (CORMs). ${ }^{73}$ These molecules release CO, either spontaneously or when exposed to light, ${ }^{74}$ in cell culture media or organ perfusion systems. The resulting CO concentration depends on the balance between the rate of CORM $\mathrm{CO}$ release and the rate of loss of $\mathrm{CO}$ to the environment, factors that are poorly characterized. Depending on the CORM molecule used and the environmental conditions (eg, $\mathrm{pH}$ ), these agents release $\mathrm{CO}$ with half-times varying from a few minutes to hours. ${ }^{75} \mathrm{~A}$ conventional application is to use a CORM bathing concentration of $30 \mu \mathrm{M}$, which could produce a $\mathrm{CO}$ concentration ranging from $30 \mu \mathrm{M}$, if completely and rapidly released, down to much lower concentrations if released slowly. However, the final $\mathrm{CO}$ concentration is unlikely to be less than about $5 \mu \mathrm{M}$, a relatively high concentration that markedly inhibits COX. Consistent with this evidence, there is suggestive evidence that the $\mathrm{CO}$ activation of the L-type $\mathrm{Ca}^{++}$channel $^{76}$ and the delayed rectifier Kv2.1 potassium channel ${ }^{77}$ are secondary to $\mathrm{COX}$ inhibition and the corresponding ROS production.

The binding of $\mathrm{CO}$ to several clotting factors (fibrinogen, plasmin, and $\alpha_{2}$-antiplasmin) results in increased rate of clot formation and stronger clots. ${ }^{78}$ It is thought that the $\mathrm{CO}$ interacts with these proteins via an associated heme. ${ }^{79,80}$ Since the $\mathrm{CO}$ concentrations required in in vitro assays are 
very large (eg, $50 \mu \mathrm{M} \mathrm{CORM}^{80}$ ), it is unlikely that this $\mathrm{CO}$ binding is physiologically significant.

\section{$\mathrm{HO}$ activity, heme substrate concentration, and the endogenous rate of $\mathrm{CO}$ tissue production}

As discussed in the "Specific CO sensors or receptors" section, the lowest $\mathrm{P}_{\mathrm{CO}}$ concentration shown to produce an observable specific second messenger effect in the most sensitive tissues (pig pial vessels) is about $0.09 \mathrm{mmHg}(0.1 \mu \mathrm{M})$. Thus, the tissue $\mathrm{CO}$ concentration must be raised at least $50 \times$ (and in most systems 500 $\times$ ) higher than the usual blood concentration of $0.0019 \mu \mathrm{M}$ (Table 1) to produce a physiological response. In other words, $\mathrm{CO}$ production by tissue $\mathrm{HO}$ must be sufficiently rapid to at least temporarily maintain a concentration of $0.1 \mu \mathrm{M}$ in the presence of diffusion to the local blood sink. This section and Table 2 summarize the very limited available experimental data on the rates of the endogenous tissue $\mathrm{CO}$ production rates.

Whole animal measurements of $\mathrm{CO}$ production provide insight into the maximal possible rate of second messenger $\mathrm{CO}$ production. The first entry in Table 2 is the total rate of human

Table 2 Hemoxygenase activity and endogenous $\mathrm{CO}$ production rates

\begin{tabular}{|c|c|c|c|}
\hline Tissue & $\begin{array}{l}\text { Rate } \mathbf{n m o l} / \mathrm{g} \\
\text { cell/h }\end{array}$ & Method & Comments \\
\hline \multicolumn{4}{|l|}{ Average human } \\
\hline \multicolumn{4}{|l|}{ CO output } \\
\hline Total daily output ${ }^{81}$ & 0.27 & & \\
\hline $\begin{array}{l}\text { Maximum available } \\
\text { CO signaling }\end{array}$ & 0.02 & $\begin{array}{l}\text { Assume } 7.5 \% \\
\text { of total }\end{array}$ & $=\mathrm{MaxCO}$ \\
\hline $\begin{array}{l}\text { Rat heme oxygenase } \\
\text { activity } 110\end{array}$ & & $\begin{array}{l}\text { Hematin } \\
\text { substrate }\end{array}$ & $\begin{array}{l}\text { Optimal } \\
\text { conditions }\end{array}$ \\
\hline Spleen & $580 * *$ & & \\
\hline Brain & $531 * *$ & & \\
\hline Heart & $96 * *$ & & \\
\hline $\begin{array}{l}\text { Aortic smooth } \\
\text { muscle cells }{ }^{\prime \prime \prime}\end{array}$ & $8^{*}$ & $\begin{array}{l}\mathrm{CO} \\
\text { production }\end{array}$ & $\begin{array}{l}\text { Maximally } \\
\text { stimulated }\end{array}$ \\
\hline $\begin{array}{l}\text { Olfactory receptor } \\
\text { neurons }{ }^{49}\end{array}$ & $26^{*}$ & $\begin{array}{l}{ }^{14} \mathrm{CO} \text { from } \\
{ }^{14} \mathrm{C} \text { glycine }\end{array}$ & $\begin{array}{l}\text { Maximally } \\
\text { stimulated }\end{array}$ \\
\hline $\begin{array}{l}\text { Olfactory receptor } \\
\text { neurons }{ }^{49}\end{array}$ & $10 *$ & $\begin{array}{l}\text { Bilirubin } \\
\text { production }\end{array}$ & $\begin{array}{l}\text { Maximally } \\
\text { stimulated }\end{array}$ \\
\hline Astrocyte ${ }^{1 / 2}$ & $10 *$ & $\begin{array}{l}\mathrm{CO} \\
\text { production }\end{array}$ & $\begin{array}{l}\text { Maximally } \\
\text { stimulated }\end{array}$ \\
\hline $\begin{array}{l}\text { Piglet cerebral } \\
\text { vessel }^{113}\end{array}$ & $140 *$ & $\begin{array}{l}\mathrm{CO} \\
\text { production }\end{array}$ & $\begin{array}{l}\text { Maximally } \\
\text { stimulated }\end{array}$ \\
\hline Cerebellar slices ${ }^{1 / 4}$ & 3,400 & $\begin{array}{l}\mathrm{CO} \text { capture } \\
\text { by } \mathrm{Hb}\end{array}$ & Basal \\
\hline
\end{tabular}

Notes: *Assume $0.1 \mathrm{~g}$ protein per g cell; $115 *$ *assume $0.05 \mathrm{~g}$ microsomes per g cell. ${ }^{116}$ Abbreviations: $\mathrm{Hb}$, hemoglobin; $\mathrm{MaxCO}$, estimated maximum average human $\mathrm{CO}$ output rate available for messenger signaling, total $\mathrm{CO}$ output produced for $\mathrm{CO}$ messenger signaling.
CO production of about $0.27 \mathrm{nmol} / \mathrm{g} / \mathrm{h} .{ }^{81}$ Of this, about $75 \%$ is accounted for by red cell turnover, and another $10 \%-15 \%$ is produced by the liver (eg, cytochrome $\mathrm{P}_{450}$ turnover). ${ }^{82}$ To this should be added the basal turnover of the rest of the body's heme. For example, a $70 \mathrm{~kg}$ human has about $30 \mathrm{~kg}^{83}$ of muscle containing about $4.4 \mathrm{~g} \mathrm{Mb} / \mathrm{kg}$ muscle,${ }^{84}$ or a total of 7.8 mmole of $\mathrm{Mb}$. If this muscle $\mathrm{Mb}$ turns over just once/ year it would release about $0.012 \mathrm{nmol} / \mathrm{g} / \mathrm{h}$, or another $5 \%$ of the total CO turnover. In addition, another $5 \%-10 \%$ of the total production could result from the turnover of muscle cytochrome. Thus, the routine "housekeeping" turnover of heme can readily account for the entire $\mathrm{CO}$ output of healthy subjects, and CO produced for signaling can only be a trivial fraction of the normal total production. For the purposes of discussion in this paper, we will assume that a maximum $7.5 \%$ of the total daily CO production, or about $0.02 \mathrm{nmol} / \mathrm{g} / \mathrm{h}$, could possibly be associated with specific $\mathrm{CO}$ second messenger signaling. This value, which is possibly an overestimate, will be referred to as the MaxCO rate (Table 2).

Endogenous tissue $\mathrm{CO}$ production is severely substrate limited. Tissue $\mathrm{HO}$ activity assayed in the presence of excess substrate (hematin) releases $\mathrm{CO}$ at a rate thousands of times greater than MaxCO (Table 2). Even a tissue with a relatively low $\mathrm{HO}$ activity, such as the heart, in the presence of unlimited substrate, produces $\mathrm{CO}$ at a rate that is $4,800 \times \mathrm{MaxCO}$. These tissue $\mathrm{HO}$ assays measure the total $\mathrm{HO}$ activity (HO-1 plus HO-2). Tissue $\mathrm{HO}$ activity is variable because $\mathrm{HO}-1$ induction results in marked changes in the total activity, with 5 -fold increases measured in whole liver $^{85}$ and 10 -fold increases seen in cell culture. ${ }^{86}$

In theory, if the physiological endogenous tissue heme substrate concentration was known, $\mathrm{HO}$ enzyme activities could be used to predict endogenous $\mathrm{CO}$ production. However, since there is very little knowledge of what constitutes the heme source for signaling reactions, much less the effective concentration of this substrate, it is not possible to predict $\mathrm{CO}$ production from $\mathrm{HO}$ activity, and such information must be derived from direct measurements of tissue $\mathrm{CO}$ release.

There have been only a few direct experimental measurements of endogenous $\mathrm{CO}$ tissue production in the absence of additional heme substrate (summarized in Table 2). Since CO production is low under physiological conditions, virtually all non-heme-enriched studies have employed non-physiological conditions (eg, enrichment with glutamate) to enhance $\mathrm{CO}$ release. It can be seen from Table 2 that the reported local tissue production rates are from 400 to $170,000 \times$ greater than MaxCO. The non-physiological nature of some of these values is illustrated by the production rate reported for cerebellar 
slices $(3,400 \mathrm{nmol} / \mathrm{g}$ cell $/ \mathrm{h})$. Just $6 \mathrm{~g}$ of this cerebellar tissue would generate $\mathrm{CO}$ at the same rate as does the total human body. Obviously, these measurements cannot represent the average $\mathrm{CO}$ production of these tissues and must correspond to some sort of stimulated condition, presumably initiated by the experimental tissue conditions.

The next section, the "Quantitative modeling of the steady state and time-dependent tissue $\mathrm{CO}$ in the presence of the blood sink" section, discusses the tissue $\mathrm{P}_{\mathrm{CO}}$ produced by the endogenous tissue $\mathrm{CO}$ production. As a benchmark, the reported rate $(\mathrm{M})$ of $\mathrm{CO}$ produced by piglet cerebral vessels (140 nmol/g cell/h; Table 2) will be assumed to be the best estimate of the maximum tissue $M$ value. Since extrapolation of this rate to all cells in the body yields a value 7,000 $\times$ greater than $\mathrm{MaxCO}$, this putative messenger $\mathrm{CO}$ production rate must occur either in very limited tissue regions (eg, pial vessels) and/or for very short time periods. For example, just $10 \mathrm{~g}$ of tissue producing $\mathrm{CO}$ at this rate equals the maximum total human $\mathrm{CO}$ production rate available for signaling.

A neglected but important question is the nature of the heme substrate that supports this messenger $\mathrm{CO}$ production, a question that remains unresolved. ${ }^{87}$ Although a "free heme pool" has been proposed, there is no evidence to support this proposal. ${ }^{87}$ Liver and erythroid cells are known to have rapid rates of heme enzyme and $\mathrm{Hb}$ synthesis, respectively, and many of the details of the control of heme biosynthesis in these tissues are well understood. Although other tissues are thought not to possess extensive biochemical pathways dedicated to heme synthesis, ${ }^{87}$ this contention is not supported by measurements of messenger ribonucleic acid (mRNA) levels of 5-aminolevulinic acid synthase-1, which is thought to be the rate-limiting step in heme synthesis, with the brain, kidney, and heart having 5-aminolevulinic acid synthase-1 levels at about $40 \%$ of the liver. ${ }^{88}$ There seems to be no question that about $75 \%$ of the total human $\mathrm{CO}$ production (and correspondingly, heme production and breakdown) is due to red blood cell turnover, with most of the remaining $\mathrm{CO}$ production due to turnover of heme in the liver. ${ }^{89}$ The rates of endogenous $\mathrm{CO}$ production listed in Table 2 for maximally stimulated tissues, if correct, correspond to huge rates of heme turnover. For example, of the total human daily $\mathrm{CO}$ production of $19 \mu$ mole $/ 70 \mathrm{~kg} / \mathrm{h},{ }^{81}$ about $15 \%$ takes place in the liver,${ }^{90}$ corresponding to a rate of liver CO production (or heme synthesis and breakdown) of about $1.9 \mathrm{nmol} / \mathrm{g} / \mathrm{h}$. This rate is only $1 / 10$ th to $1 / 100$ th of the rates listed in Table 2 for arteriolar or nerve cells. Although these rates might be present for only relatively short time periods, they would still require large amount of heme synthesis. For example, the major heme protein in smooth muscle is COX, with a maximal concentration of $30 \mathrm{nmol} / \mathrm{g}^{91}$ (smooth muscle has very low $\mathrm{Mb}$ concentrations ${ }^{92}$ ). The reported pial arterial $\mathrm{CO}$ production of $140 \mathrm{nmol} / \mathrm{g} / \mathrm{h}$ (Table 2 ) would require turnover of the entire heme COX content of the arteriole wall (two hemes per COX) every 25 minutes. Clearly, much more study of the details of the heme substrate utilized by $\mathrm{HO}$ is required for an understanding of the biochemistry of the $\mathrm{CO}$ signaling mechanism.

\section{Quantitative modeling of the steady state and time-dependent tissue $\mathrm{CO}$ in the presence of the blood sink}

As discussed, the local $\mathrm{CO}$ concentration required for a biological effect, eg, in piglet pial arterioles, is at least $50 \times$ greater than the blood concentration. Although it is conventionally assumed that such high tissue concentrations can be achieved locally via HO-catalyzed release of $\mathrm{CO},{ }^{10}$ the quantitative requirements of this assumption have not been previously evaluated. In this section, a physical model of a tissue region bathed by the blood $\mathrm{Hb}$ sink will be presented. Two different geometric arrangements will be considered. The first, representative of an arteriole or artery, consists of a cylindrical shell (the arteriolar wall) with a blood-perfused lumen. The second is representative of a solid tissue (eg, brain) penetrated by an array of capillaries. Although both of these models are idealized, they provide first-order estimates of the predicted local tissue $\mathrm{CO}$ concentration as a function of the rate of production of $\mathrm{CO}$ and the geometric diffusion distances between tissue and blood.

Figure 3 shows a diagram of the arteriolar model. It is assumed that $\mathrm{CO}$ is produced at a uniform rate $\mathrm{M}$ throughout the wall of the pial arteriole or the rat tail artery. The $\mathrm{P}_{\mathrm{CO}}$ in the vascular lumen is fixed at $P_{B}$, the normal blood value. It is assumed that the outer wall of the vessel is impermeable to CO. This assumption actually leads to an overestimate of the true concentration in the wall, because there will be some diffusion through the outer wall toward more distant circulating blood. For pial vessels, there may be an additional $\mathrm{CO}$ production from the astrocytes that form a sheath around the arteriole ${ }^{93}$ Since this sheath is only about $1 \mu \mathrm{m}$ thick, ${ }^{94}$ it will be assumed that it can be simply added to the vessel wall thickness.

In the steady state, the $\mathrm{P}_{C O}$ in the vessel wall $(\mathrm{P}(\mathrm{r}))$ as a function of the radial distance (r) from the center of the vessel is described by the Krogh-Erlang equation (with a rate $\mathrm{M}$ of 


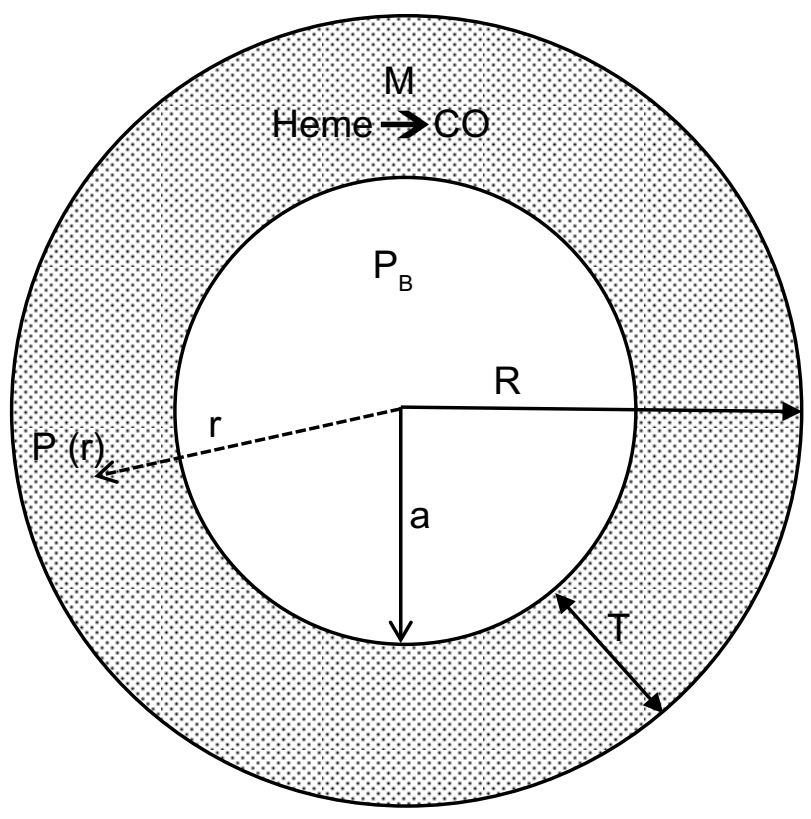

Figure 3 Diagram of the model used to model the pial arteriole or the rat tail artery. It is assumed that there is uniform rate of $\mathrm{CO}$ production $(\mathrm{M})$ in the arterial wall (thickness $=\mathrm{T}$ ). The outer wall of the artery is assumed to be impermeable to $\mathrm{CO}$, and the diffusion of $\mathrm{CO}$ to the blood sink $\left(\mathrm{P}_{C O}=\mathrm{P}_{\mathrm{B}}\right)$ sets up a steady state $\mathrm{P}_{c O}$ gradient $(=P(r))$ in the vessel wall.

Abbreviation: $\mathrm{P}_{\mathrm{CO}}, \mathrm{CO}$ partial pressure; $\mathrm{P}(\mathrm{r}), \mathrm{CO}$ partial pressure at radial position $r$ in arteriole wall; $P_{B}$, $C O$ partial pressure of blood; a, radius of arteriole lumen; $\mathrm{R}$, outer wall arteriole radius; $\mathrm{T}$, arteriole wall thickness.

$\mathrm{CO}$ production in place of the classically employed rate of oxygen consumption): ${ }^{95}$

$$
P(r)=P_{B}+\frac{M}{2 K}\left[R^{2} \ln \left(\frac{r}{a}\right)+\left(a^{2}-r^{2}\right) / 2\right]
$$

where $\mathrm{P}_{\mathrm{B}}$ is the blood $\mathrm{P}_{\mathrm{CO}}$, $\mathrm{a}$ is the radius of the blood lumen, and $\mathrm{R}$ is the outer radius of the arteriole (plus astrocyte for pial vessels), which is equal to $(\mathrm{a}+\mathrm{T})$, where $\mathrm{T}$ is the wall thickness, and $\mathrm{K}$ is the Krogh diffusivity $=\alpha \mathrm{D}$, where $\mathrm{D}$ is the tissue $\mathrm{CO}$ diffusion coefficient and $\alpha$ is the $\mathrm{CO}$ solubility $\left(\mathrm{K}=1.77 \times 10^{-5} \mathrm{nmol} / \mathrm{cm} / \mathrm{mmHg} / \mathrm{s}\right.$; Table 1$)$. The maximum tissue $\mathrm{CO}$ concentration $\left(\mathrm{P}_{\max }\right)$ is at the outer vessel wall $(\mathrm{r}=\mathrm{R})$ :

$$
P_{\max }=P_{B}+\frac{M}{2 K}\left[R^{2} \ln \left(\frac{R}{a}\right)+\left(a^{2}-R^{2}\right) / 2\right]
$$

The pial arteriole radius $(\mathrm{R})$ is about $30 \mu \mathrm{m},{ }^{60,67}$ and because the ratio of (arterial wall thickness)/ $\mathrm{R}$ is about $0.2,{ }^{96}$ $\mathrm{T}$ (including the $1 \mu \mathrm{m}$ thick astrocyte) is about $7 \mu \mathrm{m}$, and $\mathrm{a}=23 \mu \mathrm{m}$. It will be assumed that $P_{B}$ is equal to the normal human blood value of $0.0019 \mathrm{mmHg}$ (Table 1). Note that although most of the tissue $\mathrm{CO}$ is bound by tissue heme and is not free, this binding does not enter the steady state solution
(Equation 14), because only the diffusion of the free $\mathrm{CO}$, characterized by the $\mathrm{P}_{\mathrm{CO}}$, needs to be considered.

Figure 4 shows a plot of Equation 14 of the pial arteriole tissue $\mathrm{P}_{\mathrm{CO}}$ as a function of the radial distance from the inner wall of the vessel. (All calculations described here were performed using the Maple (Maplesoft ${ }^{\circledR}$ ) plotting and equation solvers). The solid lines correspond to different values of $\mathrm{M}$, the rate of tissue $\mathrm{CO}$ production. It can be seen that for $\mathrm{M}=280 \mathrm{nmol} / \mathrm{g}$ tissue $/ \mathrm{h}$ (the black line; twice the reported maximal experimental value for pial vessels), the maximum tissue $\mathrm{P}_{\mathrm{CO}}$ is only $0.0031 \mathrm{mmHg}$ (63\% greater than the blood), 30 -fold less than the minimum $\mathrm{P}_{\mathrm{CO}}$ required for an observable biological effect $(0.1 \mathrm{mmHg}$; Table 1$)$. To raise tissue $\mathrm{P}_{\mathrm{CO}}$ to the biologically effective value of $0.1 \mathrm{mmHg}$ requires an $\mathrm{M}$ of 28,000 nanomole/g tissue/h (green line, Figure 4), 200-fold greater than the maximal observed rate of pial arteriole tissue $\mathrm{CO}$ production. To put this requisite $\mathrm{CO}$ production rate $(28,000 \mathrm{nmol} / \mathrm{g} / \mathrm{h})$ into physiological perspective, just $1.5 \mathrm{~g}$ of tissue producing $\mathrm{CO}$ at this rate for 1 hour would yield $7.5 \%$ of the total daily body $\mathrm{CO}$ production, which is the maximal estimate of the $\mathrm{CO}$ available for signaling in the entire human body. The above analysis indicates that the maximally observed rates of tissue $\mathrm{CO}$ production cannot raise the pial arteriolar $\mathrm{P}_{\mathrm{CO}}$ to the $0.1 \mathrm{mmHg}$ value required for dilation, raising the question of what the function of this well-characterized $\mathrm{CO}$ response mechanism is. One possibility is that this $\mathrm{CO}$ response mechanism is only important during pathological

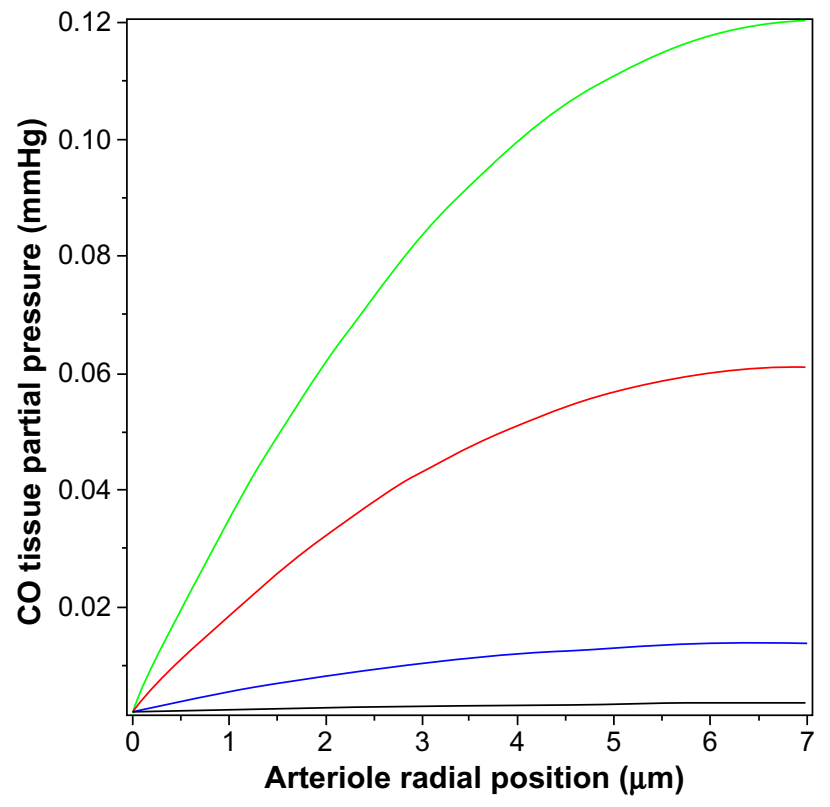

Figure 4 Steady state $P_{c o}$ in wall of pial arteriole as a function of the radial distance from the blood surface for varying rates of tissue $\mathrm{CO}$ production $(\mathrm{M})$ (black line $=280$, blue line $=2,800$, red line $=14,000$, and green line $=28,000 \mathrm{nmol} / \mathrm{g}$ cell $/ \mathrm{h}$ ). Abbreviation: $\mathrm{P}_{\mathrm{CO}}, \mathrm{CO}$ partial pressure. 
conditions of low arterial perfusion, conditions when the blood would no longer function as an infinite sink. This is discussed in more detail in the concluding discussion (the "Discussion: does HO function via its release of CO?" section).

The value of the tissue $\mathrm{P}_{\max }$ (Equation 15) for a given rate of $\mathrm{CO}$ production increases as the thickness of the tissue-producing region and the distance the $\mathrm{CO}$ must diffuse to reach the blood sink increases. The relative thinness of the pial arteriole (plus astrocyte) wall $(\approx 7 \mu \mathrm{m})$ is the major factor constraining the ability of endogenous production to raise the tissue $\mathrm{P}_{\mathrm{CO}}$. The rat tail artery, another $\mathrm{CO}$ responsive experimental model, ${ }^{62}$ has a much thicker wall of about $117 \mu \mathrm{m}$, with a luminal radius of about $93 \mu \mathrm{m},{ }^{97}$ and would be expected to have a much higher tissue $\mathrm{P}_{\mathrm{CO}}$ for a given endogenous production rate. (The walls of vessels of this size are apparently avascular ${ }^{98,99}$ ). However, the lowest stimulatory $\mathrm{CO}$ concentration observed for these vessels is about $10 \mathrm{mmHg} .{ }^{62}$ Figure 5 shows the corresponding plot of tissue $\mathrm{P}_{\mathrm{CO}}$ for a rat tail artery with these dimensions. It can be seen that the tissue $\mathrm{P}_{\mathrm{CO}}$ is much greater than that of the pial arteriole (Figure 4) for the same values of $\mathrm{M}$. The lowest production rate plotted in Figure 5 is $280 \mathrm{nmol} / \mathrm{g} / \mathrm{h}(35 \times$ the $8 \mathrm{nmol} / \mathrm{g} / \mathrm{h}$ production rate observed for cultured aortic muscle tissue), which yields a $\mathrm{P}_{\max }$ of less than $0.4 \mathrm{mmHg}$. As shown in Figure 5, the $\mathrm{CO}$ production rate would have to be on the order of $14,000 \mathrm{nmol} / \mathrm{g} / \mathrm{h}$ to develop a $\mathrm{CO}$

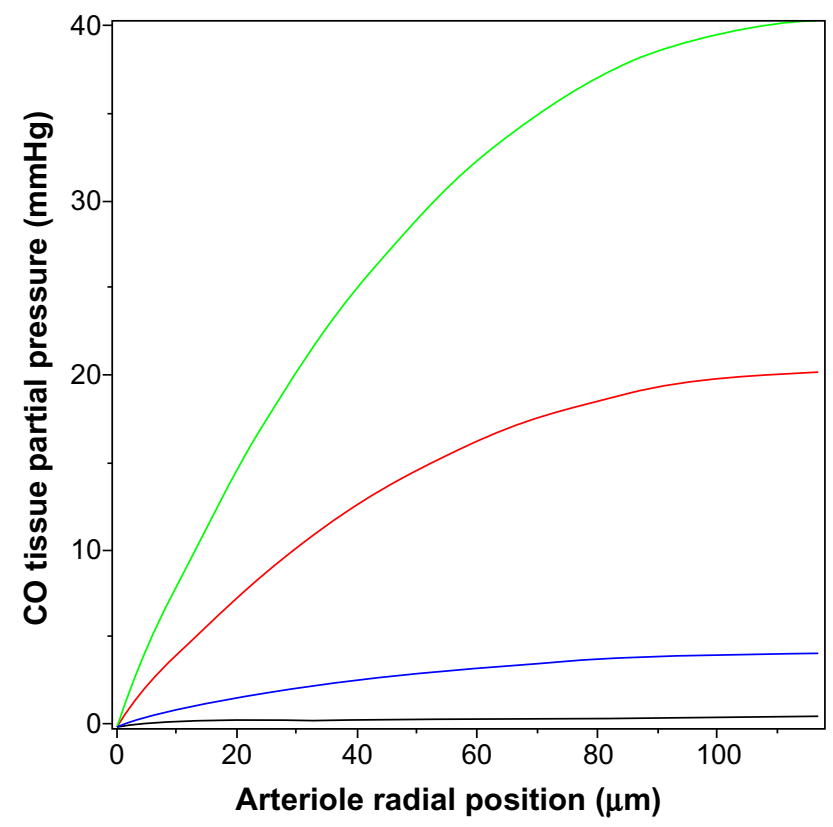

Figure 5 Steady state $P_{c o}$ in wall of rat tail artery as a function of the radial distance from the blood surface for varying rates of tissue $\mathrm{CO}$ production (M) (black line $=280$, blue line $=2,800$, red line $=\mid 4,000$, and green line $=28,000 \mathrm{nmol} / \mathrm{g}$ cell $/ \mathrm{h}$ ). Abbreviation: $\mathrm{P}_{\mathrm{CO}}$, CO partial pressure. concentration in excess of the $10 \mathrm{mmHg}$ required for significant rat tail artery relaxation. Thus, even for this much thicker wall artery, the measured local rate of $\mathrm{CO}$ production is not sufficient to produce the $10 \mathrm{mmHg} \mathrm{P}_{\mathrm{CO}}$ values that are required for activation of the effector mechanism.

The above two cases of $\mathrm{CO}$ responsiveness in vessel walls are special cases that lend themselves to relatively straightforward modeling. In contrast, most of the putative signaling actions of $\mathrm{CO}$ are for solid tissues, such as the brain, ${ }^{8}$ which have much more complicated blood perfusion geometry. As a first approximation, the tissue $\mathrm{CO}$ in the brain tissue can again be modeled using the Krogh cylinder model, ${ }^{95}$ based on the tissue cross-section shown in Figure 6. It is assumed that the capillaries have a symmetric hexagonal arrangement. Since the cylindrical surface represented by the dashed line in Figure 6 is equidistant between neighboring capillaries, there will be no diffusion of $\mathrm{CO}$ across this surface, and it can be assumed to be an impermeable barrier. Thus, the cross-hatched cylindrical region becomes mathematically identical to the arteriole wall (Figure 3), with a tissue radius $\mathrm{R}$ equal to one-half the intercapillary distance, and a radius (a) equal to the capillary radius. In the following calculation, it will be assumed that $\mathrm{R}=50 \mu \mathrm{m}$ and $\mathrm{a}=3 \mu \mathrm{m}$, and that the capillary blood acts as a sink, with a $\mathrm{P}_{\mathrm{CO}}$ equal to that of the blood $\left(\mathrm{P}_{\mathrm{B}}\right)$. This value for $\mathrm{R}$ is about twice the anatomical value and assumes that only every other capillary is perfused at rest. Figure 7 shows the corresponding plot of the Krogh cylinder tissue $\mathrm{P}_{\mathrm{CO}}$ as a function of the radial distance from the capillary wall for tissue production rates $(\mathrm{M})$ of 22, 220, and $2,200 \mathrm{nmol} / \mathrm{g} / \mathrm{h}$. It can be seen that in order to reach a CO $\mathrm{P}_{\max }$ of $1 \mathrm{mmHg}$ (eg, the concentration required for $\mathrm{BK}_{\mathrm{Ca}}$ channel activation) an $\mathrm{M}$ of about $2,200 \mathrm{nmol} / \mathrm{g} / \mathrm{h}$ is required. This is $16 \times$ the maximal experimental pial artery $M$, and $220 \times$ the maximal $M$ for astrocytes (Table 2), and $1 \mathrm{~g}$ of tissue producing $\mathrm{CO}$ at this rate would account for the total maximal rate of $\mathrm{CO}$ production potentially available for signaling purposes. Thus, it seems unlikely that endogenous tissue $\mathrm{CO}$ production could raise tissue $\mathrm{P}_{\mathrm{CO}}$ to $1 \mathrm{mmHg}$ in the presence of a normal blood perfusion.

In contrast, to raise tissue $\mathrm{CO} \mathrm{P}_{\text {max }}$ (Equation 15) to the $10 \mathrm{ppm}(0.0076 \mathrm{mmHg})$ required to produce a significant ROS signal (as described in the "COX binding and ROS formation" section) only requires an $\mathrm{M}$ of $13 \mathrm{nmol} / \mathrm{g} / \mathrm{h}$, roughly equal to the rate of $\mathrm{CO}$ tissue production of olfactory neurons or astrocytes (Table 2). This suggests that the control of ROS production is a realistic candidate for a $\mathrm{CO}$ signaling mechanism (as described in more detail in the "Discussion: does HO function via its release of CO?" section). 


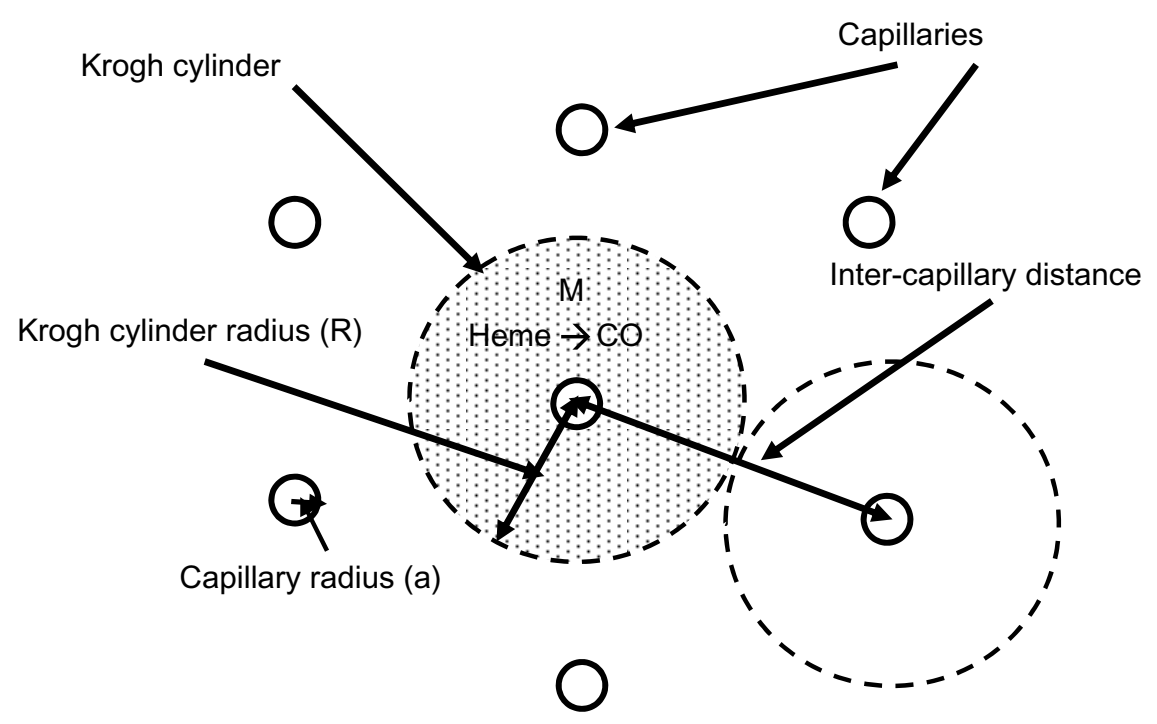

Figure 6 Diagram of the Krogh cylinder model. Because of the hexagonally symmetrical arrangement of the capillaries, there should be no diffusive CO flux across the cylindrical surface, indicated by the dashed lines, and thus, this surface can be assumed to be an impermeable barrier. The cross-hatched cylindrical region then becomes an isolated tissue region, and the diffusion equation for this region becomes mathematically identical to the arterial tissue region described in Figure 3.

Abbreviation: $\mathrm{M}$, tissue $\mathrm{CO}$ production rate.

The tissue $\mathrm{CO}$ production required to raise the tissue $\mathrm{P}_{\mathrm{CO}}$ to $1 \mathrm{mmHg}$ also can be estimated in a totally independent fashion using the following calculation. Figure 8 shows a schematic diagram of the blood-brain tissue exchange for both $\mathrm{O}_{2}$ and $\mathrm{CO}$. The driving force for $\mathrm{O}_{2}$ tissue uptake is the difference between the average $\mathrm{P}_{\mathrm{O}_{2}}^{\mathrm{B}}$ in the capillary blood (about $45 \mathrm{mmHg}$ ) and the $\mathrm{P}_{\mathrm{O}_{2}}^{\mathrm{T}}$ in the brain tissue (about $5 \mathrm{mmHg}$ ), and the driving force for $\mathrm{CO}$ leaving the tissue is

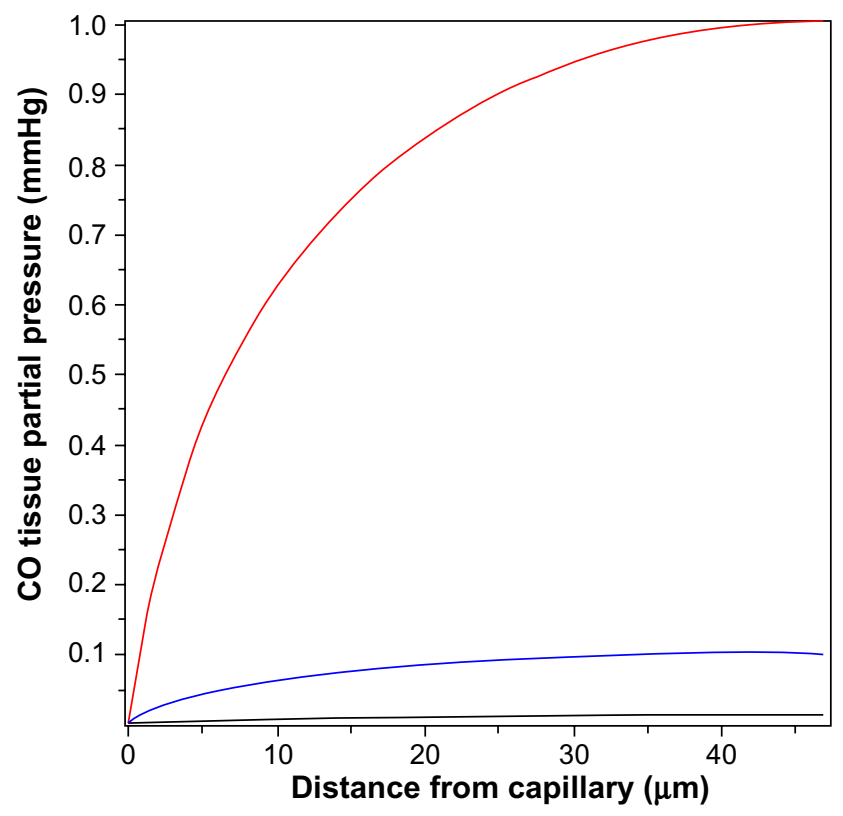

Figure 7 Steady state $P_{c o}$ in wall of Krogh cylinder solid tissue model as a function of the radial distance from the capillary surface for endogenous $\mathrm{CO}$ tissue production rates of 22 (black line), 220 (blue line), and 2,200 (red line) nmol/g cell/h. Abbreviation: $\mathrm{P}_{\mathrm{CO}}$, CO partial pressure. the difference between the average $\mathrm{P}_{\mathrm{CO}}^{\mathrm{T}}$ in the tissue $(1 \mathrm{mmHg})$ and the $\mathrm{P}_{\mathrm{CO}}^{\mathrm{B}}$ in the blood $(0.0019 \mathrm{mmHg})$. Since the complex tissue geometry and diffusion distances are identical for $\mathrm{O}_{2}$ and $\mathrm{CO}$, the $\mathrm{CO}$ flux $\left(\mathrm{J}_{\mathrm{CO}}\right)$ should be related to the $\mathrm{O}_{2}$ flux $\left(\mathrm{J}_{\mathrm{O}_{2}}\right)$ by the relation:

$$
J_{C O}=\frac{K_{C O}\left(\mathrm{P}_{C O}^{T}-P_{C O}^{B}\right)}{K_{O_{2}}\left(\mathrm{P}_{O_{2}}^{B}-P_{O_{2}}^{T}\right)} J_{O_{2}}
$$

where $\mathrm{K}_{\mathrm{CO}}$ and $\mathrm{K}_{\mathrm{O}_{2}}$ are the $\mathrm{CO}$ and $\mathrm{O}_{2}$ tissue diffusivities, and the ratio $\left(\mathrm{K}_{\mathrm{O}_{2}} / \mathrm{K}_{\mathrm{CO}}\right)$ is about $1.32 .{ }^{68,100} \mathrm{~A}$ typical value of human brain oxygen consumption $\left(\mathrm{J}_{\mathrm{O}_{2}}\right)$ is about $120 \mu \mathrm{m} / \mathrm{g} / \mathrm{h} .{ }^{101}$ Thus, the $\mathrm{CO}$ flux $\mathrm{J}_{\mathrm{CO}}$ from the brain to the blood, ie, the rate of tissue CO production for $\mathrm{P}_{\mathrm{CO}}^{\mathrm{T}}$ of $1 \mathrm{mmHg}$ and $\mathrm{P}_{\mathrm{CO}}^{\mathrm{B}}=0.0019 \mathrm{mmHg}$, is about $2,270 \mathrm{nmol} / \mathrm{g} / \mathrm{h}$ - surprisingly close to the value of 2,200 $\mathrm{nmol} / \mathrm{g} / \mathrm{h}$ estimated using the brain Krogh cylinder model, as described earlier in this section.

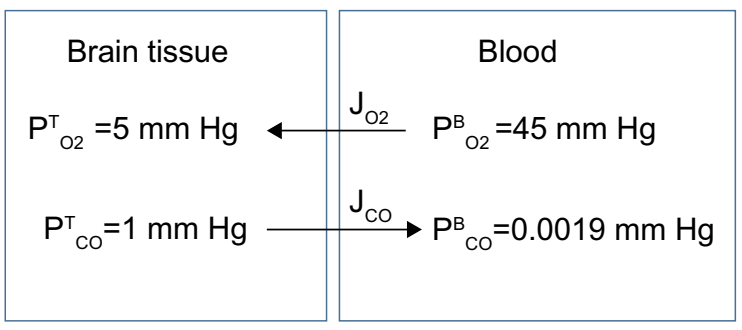

Figure 8 Schematic diagram showing the diffusional exchange of $\mathrm{O}_{2}$ and $\mathrm{CO}$ between brain tissue and capillary blood where $\mathrm{J}_{\mathrm{O}_{2}}$ and $\mathrm{J}_{\mathrm{CO}}$ are the diffusional $\mathrm{O}_{2}$ and $\mathrm{CO}$ fluxes, respectively. Because the geometry is identical for $\mathrm{O}_{2}$ and $\mathrm{CO}$, the fluxes should be related by the relative $\mathrm{O}_{2}$ and $\mathrm{CO}$ tissue diffusivities. 
Another question that can be examined quantitatively is the time constant for changes in the tissue $\mathrm{P}_{\mathrm{CO}}$. If, for example, $\mathrm{CO}$ was a regulator of arteriolar dilation, then changes in $\mathrm{P}_{\mathrm{CO}}$ presumably should occur in times of minutes or less. To answer this question, one must solve the general time-dependent equation in cylindrical coordinates:

$$
(\alpha / f) \frac{\partial P(r, t)}{\partial t}=K \frac{\partial^{2} P(r, t)}{\partial t^{2}}+(K / \mathrm{r}) \frac{\partial P(r, t)}{\partial r}+M
$$

where $\alpha$ is the $\mathrm{CO}$ solubility (Table 1 ), $\mathrm{K}$ is the tissue $\mathrm{CO}$ diffusivity, and $\mathrm{M}$ is the rate of tissue $\mathrm{CO}$ production. This equation depends on tissue heme $\mathrm{CO}$ binding and buffering, and the critical factor that accounts for this buffering in Equation 17 is $\mathrm{f}$, which is defined as the fraction of the tissue $\mathrm{CO}$ that is free (ie, unbound). Assuming that the binding results from a single saturable binding site with concentration $A$ and association constant $K_{A}$, $f$ is described by:

$$
f=\frac{1+\alpha K_{A} P(r, t)}{1+\alpha K_{A} P(r, t)+K_{A} A}
$$

This model (Equations 17 and 18) will be applied in this discussion to determine the time course of the rise in tissue $\mathrm{CO}$ in the rat tail artery model described previously in this section. It will be assumed that at time $(\mathrm{t})=0$, the $\mathrm{CO}$ production is turned on at a rate $(\mathrm{M})$ of $2,800 \mathrm{nmol} / \mathrm{g}$ cell/h, which, at the steady state, produces the tissue profile described by the blue line in Figure 5. Because smooth muscle has very low $\mathrm{Mb}$ concentration, ${ }^{92}$ it is assumed that the main $\mathrm{CO}$ binding protein is COX. As discussed in the " $\mathrm{Hb}$ and $\mathrm{Mb}$ $\mathrm{CO}$ binding and pharmacokinetics" section, $\mathrm{O}_{2}$ and $\mathrm{CO}$ are competing for the same binding site in $\mathrm{COX}$, described by Equation 12, so that the apparent $\mathrm{K}_{\mathrm{A}}$ for $\mathrm{CO}$ will depend on the $\mathrm{P}_{\mathrm{O}_{2}}$. In the following calculation, it will be assumed that the tissue $\mathrm{P}_{\mathrm{O}_{2}}$ is fixed at $3 \mathrm{mmHg}$ and that the apparent $\mathrm{CO} \mathrm{K}_{\mathrm{d}}$ is $1 \mu \mathrm{M}$, corresponding to a $\mathrm{K}_{\mathrm{A}}$ of $1 \mu \mathrm{M}^{-1}$. The tissue COX concentration (A) will be set at $30 \mu \mathrm{M}$, the value reported for heart muscle. ${ }^{91}$ Equations 17 and 18 were numerically integrated to generate the curves shown in Figure 9, which plot the tissue $\mathrm{P}_{\mathrm{CO}}$ as a function of distance from the blood for times of 10 seconds (black curve), 50 seconds (red curve), 100 seconds (green curve), and infinity (blue curve) after turning on the $\mathrm{CO}$ tissue production. It can be seen that for the large rate of production $(\mathrm{M}=2,800 \mathrm{nmol} / \mathrm{g}$ cell $/ \mathrm{h})$ required to raise the steady state tissue $\mathrm{P}_{\mathrm{CO}}$ to $4 \mathrm{mmHg}$, the buffering effect is relatively small, and the steady state $(t=$ infinity) is reached in about 2 minutes. Thus, for example, $\mathrm{CO}$ might be

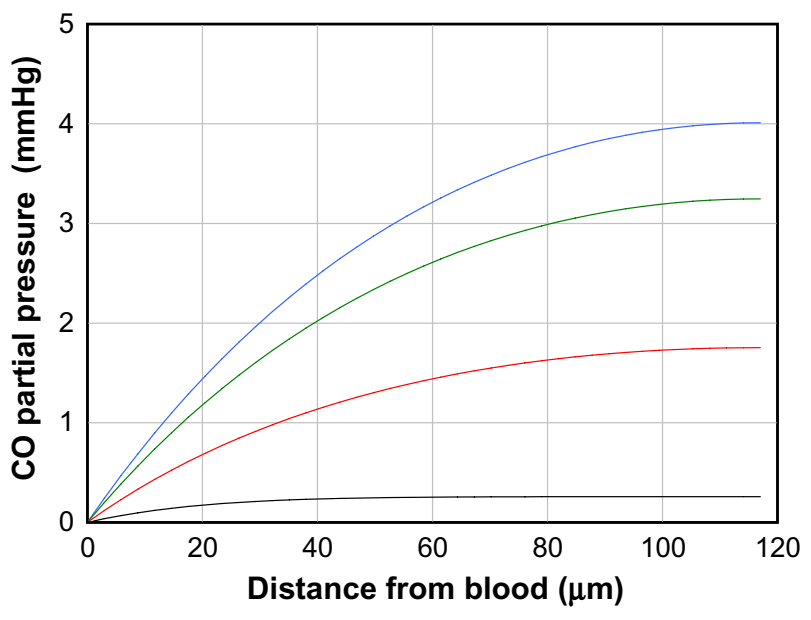

Figure 9 Artery wall $\mathrm{CO}$ partial pressure $\left(\mathrm{P}_{\mathrm{cO}}\right)$ as a function of distance from the blood surface for times of 10 seconds (black curve), 50 seconds (red curve), 100 seconds (green curve), and an infinite time (blue curve), after suddenly turning on tissue $\mathrm{CO}$ production at a rate of $2,800 \mathrm{nM} / \mathrm{g}$ cell/h. The artery has a thickness of II7 $\mu \mathrm{m}$.

able to regulate arteriolar blood flow on a minute-to-minute time scale if this extremely high rate of tissue $\mathrm{CO}$ production could be reached.

\section{Discussion: does $\mathrm{HO}$ function via its release of $\mathrm{CO}$ ?}

It is surprising that the above question should be raised, given the voluminous literature devoted to $\mathrm{HO}$ measurements and CO signaling. However, as discussed in this review, the available data do not provide clear-cut evidence that $\mathrm{CO}$ serves as the intracellular effector of $\mathrm{HO}$ activity in normally functioning tissue. The modulation of HO-1 activity that has been observed in nearly every tissue studied strongly suggests that this enzyme must have an important regulatory role in cell physiology. As emphasized in the "Introduction" section, $\mathrm{HO}$ has three other functions besides CO production: 1) catabolism of heme, 2) recycling of $\mathrm{Fe}^{2+}$, and 3) production of the anti-oxidant bilirubin. The factors that induce HO-1 are primarily events that tend to produce apoptosis or cell death, such as oxidative stress, heat shock, ischemia, radiation, hypoxia, or hyperoxia, all of which would be expected to increase heme turnover, with a consequent need for increased HO. In the great majority of studies, ${ }^{4}$ the question of the effector associated with this $\mathrm{HO}$ induction is simply ignored. Rather, $\mathrm{HO}$ modulation is regarded as the central event, and $\mathrm{CO}$ is assumed to be the mediator of $\mathrm{HO}$ activity. Rarely discussed are important quantitative physiological questions concerning this pathway, such as the tissue $\mathrm{P}_{\mathrm{CO}}$ required for the biological effect, the rate of tissue $\mathrm{CO}$ production, the identity of the $\mathrm{CO}$ receptor, and the influence 
of diffusion from tissue to blood on intracellular CO. These questions are the focus of this review.

The belief in $\mathrm{CO}$ as the mediator of $\mathrm{HO}$ activity is primarily based on the observations that $\mathrm{CO}$ is produced by tissue and that $\mathrm{CO}$ exposure alters tissue function in both in vitro and in vivo experiments. As discussed in the "HO activity, heme substrate concentration, and the endogenous rate of $\mathrm{CO}$ tissue production" section, $\mathrm{CO}$ released during the routine turnover of $\mathrm{Hb}$, hepatic heme, or other heme proteins (eg, muscle $\mathrm{Mb}$ ) can readily account for the total daily $\mathrm{CO}$ production (about $0.5 \mathrm{mmol}$ ) of normal subjects. Thus, there is no need to teleologically hypothesize a useful function for $\mathrm{CO}$, eg, intracellular signaling, simply based on $\mathrm{CO}$ production in the body. While it is not possible to exclude the possibility that a small fraction of $\mathrm{CO}$ is produced as a messenger, this production must be very small, ranging from $0 \%-7.5 \%$ of total production, or a maximal rate of 0.02 $\mathrm{nmol} / \mathrm{g} / \mathrm{h}$ (previously defined as MaxCO). To put this value of MaxCO in perspective, a tissue production rate of $100 \times$ MaxCO will only raise tissue $\mathrm{P}_{C O}$ to $0.0028 \mathrm{mmHg}$ (using the brain Krogh cylinder model, discussed in the "Quantitative modeling of the steady state and time-dependent tissue $\mathrm{CO}$ in the presence of the blood sink" section), less than twice the plasma $\mathrm{P}_{\mathrm{CO}}$ and far below the level required for any known $\mathrm{CO}$ signaling mechanism.

The reported rates of "physiological" endogenous CO production by a variety of tissue preparations are surprisingly large, 400 to $170,000 \times$ greater than MaxCO (Table 2). These clearly cannot represent the daily average rate of $\mathrm{CO}$ production of these tissues. For example, if the relative low reported rate of $10 \mathrm{nmol} / \mathrm{g} / \mathrm{h}$ for astrocytes and olfactory neurons were representative of brain tissue, then the human brain (weighing $1.5 \mathrm{~kg}$ ) would produce $0.35 \mathrm{mmol} /$ day, $70 \%$ of the total daily human $\mathrm{CO}$ output, which is far in excess $(10 \times)$ the maximal total CO possibly available for signaling in humans. One possible explanation for these high $\mathrm{CO}$ production rates measured in vitro is that the supposedly physiological experimental tissue conditions actually induce some cell damage, increasing the heme substrate concentration for $\mathrm{HO}$.

Even though these $\mathrm{CO}$ production rates cannot represent average daily rates, production in highly localized tissue regions for short time periods could create very high local $\mathrm{CO}$ production rates that could trigger second messenger effects. The crucial experimental evidence to support a messenger function for $\mathrm{CO}$ would be the demonstration that intracellular $\mathrm{CO}$ production is capable of raising the cellular $\mathrm{CO}$ concentration to a level that is known to alter cell function.
Not commonly considered is the extent to which rapid diffusion of $\mathrm{CO}$ from cells to blood limits such increases in intracellular CO concentration. As discussed in the "Specific CO sensors or receptors" section, the most sensitive specific $\mathrm{CO}$ receptor-mediated function is the dilatation of the piglet pial artery, which responds to an experimental $\mathrm{P}_{\mathrm{CO}}$ of as low as $0.1 \mathrm{mmHg}$ (presumably via activation of the $\mathrm{BK}_{\mathrm{Ca}}$ channel receptor). However, as shown in the "Quantitative modeling of the steady state and time-dependent tissue $\mathrm{CO}$ in the presence of the blood sink" section, because of the short diffusion distances between the arteriole wall and luminal blood, even the relatively high experimental in vitro pial arteriolar production rate of $140 \mathrm{nmol} / \mathrm{g} / \mathrm{h}$ can only raise the tissue CO concentration to a maximum $\mathrm{P}_{\mathrm{CO}}$ of $0.0025 \mathrm{mmHg}$. This is only $30 \%$ greater than the blood $\mathrm{P}_{\mathrm{CO}}(0.0019 \mathrm{mmHg})$, and 40-fold less than the $0.1 \mathrm{mmHg}$, required for the minimal arteriolar dilation observed with exogenous $\mathrm{CO}$ administration. In order to raise the tissue piglet artery $\mathrm{P}_{\mathrm{CO}}$ to $0.1 \mathrm{mmHg}$, given the rapid diffusion of $\mathrm{CO}$ into blood, requires rates of tissue CO production that are $100 \times$ the experimentally observed maximum tissue production rate (Figure 4).

If uptake by blood renders endogenous $\mathrm{CO}$ release grossly insufficient to serve as an effector in the most CO-responsive tissue, it seems necessary to reconsider the concept that $\mathrm{CO}$ acts as a tissue messenger, as nitric oxide does, in normally perfused tissue. The possibility remains that a $\mathrm{CO}$ regulatory mechanism might become important under conditions in which the blood sink is disabled, ie, conditions with significantly decreased blood flow. For example, piglets' brain $\mathrm{CO}$ production (as estimated from changes in cerebral spinal fluid CO) was acutely increased by a factor of 2.3 in response to hypotension, ${ }^{102}$ an increase that would not be expected to cause a rise in cellular $\mathrm{CO}$ sufficient to induce vascular dilatation if tissue perfusion remained normal. However, the combination of this relatively modest increase in $\mathrm{CO}$ production with poor perfusion could appreciably increase intracellular $\mathrm{CO}$. Although entirely speculative, this $\mathrm{CO}$ might serve as an autoregulatory factor, acting only when blood flow has dropped to low enough levels that the perfusing blood ceases to act as a CO sink.

The failure to clearly identify specific $\mathrm{CO}$ receptor mechanism(s) has re-directed attention to the possibility that $\mathrm{CO}$ acts relatively non-specifically via its binding to and inhibition of COX. As discussed in the "COX binding and ROS formation" section, concentrations of $\mathrm{CO}$ of as low as $10 \mathrm{ppm}(0.0076 \mathrm{mmHg})$ have been shown to increase ROS production secondary to COX inhibition. Thus, ROS production is by far the most sensitive potential CO signaling 
mechanism described to date, and this mechanism has been invoked as the explanation for the multiple physiological alterations observed with in vivo, low-dose $\mathrm{CO}$ exposure. For example, inhaled $\mathrm{P}_{\mathrm{CO}}$ of $25-250 \mathrm{ppm}$ for 1 hour/day, 3 days/ week for 10 weeks produces statistically significant decreases in vascular inflammation in a sickle cell mouse model. ${ }^{103}$ A similar regimen of inhaled $250 \mathrm{ppm} \mathrm{CO}$ for 1 hour/day has been shown to have an amazing variety of other effects such as reducing the rate of growth of a prostatic tumor cell line in nude mice, ${ }^{104}$ reducing pulmonary hypertension in rats, ${ }^{105}$ improving myeloid cell engraftment,${ }^{106}$ and enhancing liver regeneration. ${ }^{107}$ This evidence suggests that this short exposure to $\mathrm{CO}$ and subsequent ROS production turns on a variety of downstream processes that can have profound physiological effects. As discussed in the "COX binding and ROS formation" section, because $\mathrm{CO}$ and $\mathrm{O}_{2}$ are competing for the same COX binding site, the rate of $\mathrm{CO}$-induced COX ROS production should be critically dependent on the effective $\mathrm{pO}_{2}$. This might provide some specificity to low-dose whole animal $\mathrm{CO}$ administration - directing it to anoxic tissue regions such as tumors (eg, action of inhaled $\mathrm{CO}$ on prostatic tumors ${ }^{104}$ ) or regions where red cell sickling occurs (eg, action of inhaled $\mathrm{CO}$ on vascular inflammation in a sickle cell mouse model ${ }^{103}$ ).

These actions of a relatively low dose of $\mathrm{CO}$ exposure on COX ROS production are dramatic and raise the possibility that they reflect normal physiological control systems involving the endogenous release of $\mathrm{CO}$ via $\mathrm{HO}$ enzyme activity. However, it remains to be shown that endogenous $\mathrm{CO}$ production can raise tissue $\mathrm{P}_{\mathrm{CO}}$ to the required levels. Raising tissue $\mathrm{P}_{\mathrm{CO}}$ to $10 \mathrm{ppm}(0.0076 \mathrm{mmHg})$, which is only $4 \times$ the normal blood $\mathrm{P}_{\mathrm{CO}}$ and is the lowest concentration for which a biological effect has been reported, ${ }^{42}$ requires a tissue $\mathrm{CO}$ production rate of about $13 \mathrm{nmol} / \mathrm{g} / \mathrm{h}$ (using the brain Krogh cylinder model, discussed in the "Quantitative modeling of the steady state and time-dependent tissue $\mathrm{CO}$ in the presence of the blood sink" section). This endogenous rate of $\mathrm{CO}$ production seems feasible, because it is only $1.3 \times$ the $\mathrm{CO}$ production rate that has been reported for maximally stimulated astrocytes and olfactory receptor neurons (Table 2). However, the total body $\mathrm{CO}$ balance analysis (as discussed in the "HO activity, heme substrate concentration, and the endogenous rate of $\mathrm{CO}$ tissue production" section) places strong constraints on the normal spatial and temporal distribution of these enhanced rates. This rate of $13 \mathrm{nmol} / \mathrm{g} / \mathrm{h}$ is $650 \times$ the maximum possible average signaling rate of $\mathrm{CO}$ production for the entire body (MaxCO). Only $93 \mathrm{~g}$ of tissue producing $\mathrm{CO}$ at this rate would account for our maximal estimate of total human $\mathrm{CO}$ production that might serve a signaling function. However, an important proviso of this $\mathrm{CO}$ balance analysis is that it is based on the average normal rate of total body $\mathrm{CO}$ production. The pathological conditions associated with HO-1 induction, such as oxidative stress, heat shock, ischemia, radiation, hypoxia, or hyperoxia would be expected to produce increased cell death, with a corresponding increased heme turnover and CO production. Just a $20 \%$ increase in total body $\mathrm{CO}$ produced via such a mechanism would correspond to a $370 \%$ increase in the $\mathrm{CO}$ production that might serve a signaling function. Support for this hypothesis would be provided by measurements showing increased total body $\mathrm{CO}$ production under stress conditions.

As discussed above, endogenous $\mathrm{CO}$ production could raise tissue $\mathrm{CO}$ to the levels that are produced by exogenous administration of $10 \mathrm{ppm} \mathrm{CO}$, but it seems much less likely that endogenous $\mathrm{CO}$ production could mimic the tissue concentrations resulting from the $250 \mathrm{ppm}$ inhaled $\mathrm{CO}$ that has become a staple of experimental whole animal studies. In mice, at the end of 1 hour dosing with $250 \mathrm{ppm}$ inhaled $\mathrm{CO}$, the plasma (and tissue) $\mathrm{P}_{\mathrm{CO}}$ should have reached a value of about $200 \mathrm{mmHg}$ (as described in the " $\mathrm{Hb}$ and $\mathrm{Mb} \mathrm{CO}$ binding and pharmacokinetics" section), which requires a $350 \mathrm{nmol} / \mathrm{g} / \mathrm{h}$ rate of $\mathrm{CO}$ production, significantly larger than most of the reported tissue rates (Table 2). Just $100 \mathrm{~g}$ of tissue producing $\mathrm{CO}$ at this rate will produce $35 \mu \mathrm{mole} / \mathrm{h}$ of $\mathrm{CO}$, twice the normal total human $\mathrm{CO}$ production rate, tripling the normal human $\mathrm{CO}$ excretion rate. Such levels of $\mathrm{CO}$ excretion have only been reported in patients with hemolysis.

In summary, we utilized the uniquely non-metabolizable nature of $\mathrm{CO}$ to quantitatively model the endogenous $\mathrm{CO}$ production required to achieve various intracellular $\mathrm{CO}$ concentrations, given the rapid diffusion of $\mathrm{CO}$ from cell to blood. This modeling suggests that under normally perfused conditions, intracellular $\mathrm{CO}$ production is seemingly insufficient to induce the specific second messenger functions that have been attributed to $\mathrm{CO}$ in healthy tissue. However, it is also clear that exogenous $\mathrm{CO}$ administration can induce multiple physiological effects. The effector in these studies is thought to be ROS, released secondary to CO-induced inhibition of COX. Whether such effects can be considered a "signaling" system, as opposed to a non-specific response to cell injury, is uncertain. Our calculations suggest that endogenous $\mathrm{CO}$ production is insufficient to induce the cellular CO concentrations achieved in the usual $250 \mathrm{ppm}$ $\mathrm{CO}$ inhalation study. However, a few studies have shown that ROS production and alteration of tissue function can 
be produced by exposure to as low as $10 \mathrm{ppm}$ CO. Since this low-dose $\mathrm{CO}$ exposure produces cellular CO concentrations that might be achieved via endogenous production, such ROS release appears to provide the most plausible mechanism by which $\mathrm{CO}$ could provide an intracellular messenger function.

\section{Disclosure}

The authors report no conflicts of interest in this work.

\section{References}

1. Bernard C. Lecons sur les effects des substances toxiques et medicamenteuses. Paris: Bailliere; 1857. French.

2. Sjostrand T. The formation of carbon monoxide by the decomposition of haemoglobin in vivo. Acta Physiol Scand. 1952;26(4):338-344.

3. Ghosh D, LeVault KR, Brewer GJ. Dual-energy precursor and nuclear erythroid-related factor 2 activator treatment additively improve redox glutathione levels and neuron survival in aging and Alzheimer mouse neurons upstream of reactive oxygen species. Neurobiol Aging. 2014;35(1):179-190.

4. Maines MD. The heme oxygenase system: a regulator of second messenger gases. Annu Rev Pharmacol Toxicol. 1997;37:517-554.

5. Wu L, Wang R. Carbon monoxide: endogenous production, physiological functions, and pharmacological applications. Pharmacol Rev. 2005;57(4):585-630.

6. Ryter SW, Alam J, Choi AM. Heme oxygenase-1/carbon monoxide: from basic science to therapeutic applications. Physiol Rev. 2006;86(2):583-650.

7. Gozzelino R, Jeney V, Soares MP. Mechanisms of cell protection by heme oxygenase-1. Annual review of pharmacology and toxicology. 2010;50:323-354.

8. Queiroga CS, Vercelli A, Vieira HL. Carbon monoxide and the CNS: challenges and achievements. Br J Pharmacol. Epub April 24, 2014.

9. Gullotta F, di Masi A, Coletta M, Ascenzi P. CO metabolism, sensing, and signaling. Biofactors. 2012;38(1):1-13.

10. Heinemann SH, Hoshi T, Westerhausen M, Schiller A. Carbon monoxide - physiology, detection and controlled release. Chem Commun (Camb). 2014;50(28):3644-3660.

11. Leffler CW, Parfenova H, Jaggar JH. Carbon monoxide as an endogenous vascular modulator. Am J Physiol Heart Circ Physiol. 2011;301(1):H1-H11.

12. Maines MD, Gibbs PE. 30 some years of heme oxygenase: from a "molecular wrecking ball" to a "mesmerizing" trigger of cellular events. Biochem Biophys Res Commun. 2005;338(1):568-577.

13. Hanafy KA, Oh J, Otterbein LE. Carbon monoxide and the brain: time to rethink the dogma. Curr Pharm Des. 2013;19(15):2771-2775.

14. Agostoni A, Stabilini R, Viggiano G, Luzzana M, Samaja M. Influence of capillary and tissue $\mathrm{PO} 2$ on carbon monoxide binding to myoglobin: a theoretical evaluation. Microvasc Res. 1980;20(1): $81-87$.

15. Roughton FJW, DeLand EC, Kernohan JC, Serveringhaus JW. Some recent studies of the oxyhaemoglobin dissociation curve of human blood under physiological conditions and the fitting of the Adair equation to the standard curve. Paper presented at: Proceeding of the Alfred Benzon Symposium IV; 1972; Copenhagen, Denmark.

16. Roughton FJ. The equilibrium of carbon monoxide with human hemoglobin in whole blood. Ann NY Acad Sci. 1970;174(1):177-188.

17. Furne JK, Springfield JR, Ho SB, Levitt MD. Simplification of the end-alveolar carbon monoxide technique to assess erythrocyte survival. J Lab Clin Med. 2003;142(1):52-57.

18. Coburn RF, Forster RE, Kane PB. Considerations of the physiological variables that determine the blood carboxyhemoglobin concentration in man. J Clin Invest. 1965;44(11):1899-1910.
19. Peterson JE, Stewart RD. Absorption and elimination of carbon monoxide by inactive young men. Arch Environ Health. 1970;21(2):165-171.

20. Drabkin DL. The distribution of the chromoprotein, hemoglobin, myoglobin, and cytochrome c, in the tissues of different species and the relationship of the total content of each chromoprotein to body mass. J Biol Chem. 1950;1950(182):317-334.

21. Bruce EN, Bruce MC. A multicompartment model of carboxyhemoglobin and carboxymyoglobin responses to inhalation of carbon monoxide. J Appl Physiol (1985). 2003;95(3):1235-1247.

22. Riches AC, Sharp JG, Thomas DB, Smith SV. Blood volume determination in the mouse. J Physiol. 1973;228(2):279-284.

23. Guyton AC. Measurement of the respiratory volumes of laboratory animals. Am J Physiol. 1947;150(1):70-77.

24. Verma K, Penney DG, Helfman CC, Sutariya BB. Carboxyhemoglobin in the rat: improvements in the spectrophotometric measurement and comparison to other studies. J Appl Toxicol. 1989;9(5):323-330.

25. Reedy CJ, Elvekrog MM, Gibney BR. Development of a heme protein structure-electrochemical function database. Nucleic Acids Res. 2008;36(Database issue):D307-D313.

26. Piantadosi CA. Biological chemistry of carbon monoxide. Antioxidant Redox Signal. 2002;4(2):259-270.

27. Alonso JR, Cardellach F, López S, Casademont J, Miró O. Carbon monoxide specifically inhibits cytochrome c oxidase of human mitochondrial respiratory chain. Pharmacol Toxicol. 2003;93(3):142-146.

28. Zuckerbraun BS, Chin BY, Bilban M, et al. Carbon monoxide signals via inhibition of cytochrome c oxidase and generation of mitochondrial reactive oxygen species. FASEB J. 2007;21(4):1099-1106.

29. Petersen LC. The effect of inhibitors on the oxygen kinetics of cytochrome c oxidase. Biochim Biophys Acta. 1977;460(2):299-307.

30. Hansen FB, Nicholls P. Control of respiration in proteoliposomes containing cytochrome aa3. II. Inhibition by carbon monoxide and azide. Biochim Biophys Acta. 1978;502(3):400-408.

31. Yoshikawa S, Choc MG, O'Toole MC, Caughey WS. An infrared study of $\mathrm{CO}$ binding to heart cytochrome c oxidase and hemoglobin A. Implications re O2 reactions. J Biol Chem. 1977;252(15): 5498-5508.

32. Wohlrab H, Ogunmola GB. Carbon monoxide binding studies of cytochrome a3 hemes in intact rat liver mitochondria. Biochemistry. 1971;10(7):1103-1106.

33. Gnaiger E, Lassnig B, Kuznetsov A, Rieger G, Margreiter R. Mitochondrial oxygen affinity, respiratory flux control and excess capacity of cytochrome c oxidase. J Exp Biol. 1998;201(Pt 8):1129-1139.

34. Wilson DF, Rumsey WL, Green TJ, Vanderkooi JM. The oxygen dependence of mitochondrial oxidative phosphorylation measured by a new optical method for measuring oxygen concentration. J Biol Chem. 1988;263(6):2712-2718.

35. Coburn RF. Mechanisms of carbon monoxide toxicity. Prev Med. 1979;8(3):310-322.

36. Glabe A, Chung Y, Xu D, Jue T. Carbon monoxide inhibition of regulatory pathways in myocardium. Am J Physiol. 1998;274(6 Pt 2): H2143-H2151.

37. Chance B, Erecinska M, Wagner M. Mitochondrial responses to carbon monoxide toxicity. Ann N Y Acad Sci. 1970;174(1):193-204.

38. Cooper CE, Brown GC. The inhibition of mitochondrial cytochrome oxidase by the gases carbon monoxide, nitric oxide, hydrogen cyanide and hydrogen sulfide: chemical mechanism and physiological significance. J Bioenerg Biomembr. 2008;40(5):533-539.

39. McLennan HR, Degli Esposti M. The contribution of mitochondrial respiratory complexes to the production of reactive oxygen species. J Bioenerg Biomembr. 2000;32(2):153-162.

40. Mittler R, Vanderauwera S, Suzuki N, et al. ROS signaling: the new wave? Trends Plant Sci. 2011;16(6):300-309.

41. Sena LA, Chandel NS. Physiological roles of mitochondrial reactive oxygen species. Molecular cell. 2012;48(2):158-167.

42. Thom SR, Fisher D, Xu YA, Notarfrancesco K, Ischiropoulos H. Adaptive responses and apoptosis in endothelial cells exposed to carbon monoxide. Proc Natl Acad Sci U S A. 2000;97(3):1305-1310. 
43. Middleton ET, Morice AH. Breath carbon monoxide as an indication of smoking habit. Chest. 2000;117(3):758-763.

44. Peng CA, Palsson BO. Determination of specific oxygen uptake rates in human hematopoietic cultures and implications for bioreactor design. Ann Biomed Eng. 1996;24(3):373-381.

45. Zhang X, Shan P, Otterbein LE, et al. Carbon monoxide inhibition of apoptosis during ischemia-reperfusion lung injury is dependent on the p38 mitogen-activated protein kinase pathway and involves caspase 3 . J Biol Chem. 2003;278(2):1248-1258.

46. Ryter SW, Morse D, Choi AM. Carbon monoxide: to boldly go where NO has gone before. Sci STKE. 2004;2004(230):RE6.

47. Verma A, Hirsch DJ, Glatt CE, Ronnett GV, Snyder SH. Carbon monoxide: a putative neural messenger. Science. 1993;259(5093):381-384.

48. Stone JR, Marletta MA. Soluble guanylate cyclase from bovine lung: activation with nitric oxide and carbon monoxide and spectral characterization of the ferrous and ferric states. Biochemistry. 1994;33(18):5636-5640.

49. Ingi T, Chiang G, Ronnett GV. The regulation of heme turnover and carbon monoxide biosynthesis in cultured primary rat olfactory receptor neurons. J Neurosci. 1996;16(18):5621-5628.

50. Cary SP, Marletta MA. The case of CO signaling: why the jury is still out. J Clin Invest. 2001;107(9):1071-1073.

51. Aono $\mathrm{S}$. Biochemical and biophysical properties of the CO-sensing transcriptional activator CooA. Acc Chem Res. 2003;36(11):825-831.

52. Uchida T, Sato E, Sato A, Sagami I, Shimizu T, Kitagawa T. COdependent activity-controlling mechanism of heme-containing CO-sensor protein, neuronal PAS domain protein 2. $\mathrm{J}$ Biol Chem. 2005;280(22):21358-21368.

53. Gilun P, Stefanczyk-Krzymowska S, Romerowicz-Misielak M, Tabecka-Lonczynska A, Przekop F, Koziorowski M. Carbon monoxidemediated humoral pathway for the transmission of light signal to the hypothalamus. J Physiol Pharmacol. 2013;64(6):761-772.

54. Dioum EM, Rutter J, Tuckerman JR, Gonzalez G, Gilles-Gonzalez MA, McKnight SL. NPAS2: a gas-responsive transcription factor. Science. 2002;298(5602):2385-2387.

55. Artinian LR, Ding JM, Gillette MU. Carbon monoxide and nitric oxide: interacting messengers in muscarinic signaling to the brain's circadian clock. Exp Neurol. 2001;171(2):293-300.

56. Puranik M, Nielsen SB, Youn H, et al. Dynamics of carbon monoxide binding to CooA. J Biol Chem. 2004;279(20):21096-21108.

57. Vetri F, Choudhury MSR, Pelligrino DA, Sundivakkam P. BKCa channels as physiological regulators: a focused review. J Receptor Ligand Channel Res. 2014;7:3-13.

58. Hou S, Xu R, Heinemann SH, Hoshi T. The RCK1 high-affinity Ca2+ sensor confers carbon monoxide sensitivity to Slo1 BK channels. Proc Natl Acad Sci U S A.. 2008;105(10):4039-4043.

59. Xi Q, Tcheranova D, Parfenova H, Horowitz B, Leffler CW, Jaggar JH. Carbon monoxide activates KCa channels in newborn arteriole smooth muscle cells by increasing apparent $\mathrm{Ca} 2+$ sensitivity of alpha-subunits. Am J Physiol Heart Circ Physiol. 2004;286(2):H610-H618.

60. Knecht KR, Milam S, Wilkinson DA, Fedinec AL, Leffler CW. Timedependent action of carbon monoxide on the newborn cerebrovascular circulation. Am J Physiol Heart Circ Physiol. 2010;299(1):H70-H75.

61. Holt DC, Fedinec AL, Vaughn AN, Leffler CW. Age and species dependence of pial arteriolar responses to topical carbon monoxide in vivo. Exp Biol Med (Maywood). 2007;232(11):1465-1469.

62. Wang R, Wang Z, Wu L. Carbon monoxide-induced vasorelaxation and the underlying mechanisms. Br J Pharmacol. 1997;121(5):927-934.

63. Morita T, Perrella MA, Lee ME, Kourembanas S. Smooth muscle cellderived carbon monoxide is a regulator of vascular cGMP. Proc Natl Acad Sci U S A. 1995;92(5):1475-1479.

64. Yi L, Morgan JT, Ragsdale SW. Identification of a thiol/disulfide redox switch in the human BK channel that controls its affinity for heme and CO. J Biol Chem. 2010;285(26):20117-20127.

65. Wu JY, Qu HY, Shang ZL, et al. Reciprocal regulation of $\mathrm{Ca}(2)+-$ activated outward $\mathrm{K}+$ channels of Pyrus pyrifolia pollen by heme and carbon monoxide. New Phytol. 2011;189(4):1060-1068.
66. Williams SE, Wootton P, Mason HS, et al. Hemoxygenase-2 is an oxygen sensor for a calcium-sensitive potassium channel. Science. 2004;306(5704):2093-2097.

67. Migita CT, Matera KM, Ikeda-Saito M, et al. The oxygen and carbon monoxide reactions of heme oxygenase. J Biol Chem. 1998;273(2):945-949.

68. Altman PL, Dittmer DS. Respiration and circulation. Bethesda, MD: Federation of American Societies for Experimental Etiology; 1971:16. http://www2.epa.gov/sites/production/files/2014-03/documents/ leidyref.pdf.

69. Ortega-Sáenz P, Pascual A, Piruat JI, López-Barneo J. Mechanisms of acute oxygen sensing by the carotid body: lessons from genetically modified animals. Respir Physiol Neurobiol. 2007;157(1):140-147.

70. Wang S, Publicover S, Gu Y. An oxygen-sensitive mechanism in regulation of epithelial sodium channel. Proc Natl Acad Sci U S A. 2009;106(8):2957-2962.

71. Otterbein LE, Mantell LL, Choi AM. Carbon monoxide provides protection against hyperoxic lung injury. Am J Physiol. 1999;276(4 Pt 1): L688-L694.

72. Althaus M, Fronius M, Buchackert Y, et al. Carbon monoxide rapidly impairs alveolar fluid clearance by inhibiting epithelial sodium channels. Am J Respir Cell Mol Biol. 2009;41(6):639-650.

73. Wilkinson WJ, Kemp PJ. Carbon monoxide: an emerging regulator of ion channels. J Physiol. 2011;589(Pt 13):3055-3062.

74. Motterlini R. Carbon monoxide-releasing molecules (CO-RMs): vasodilatory, anti-ischaemic and anti-inflammatory activities. Biochem Soc Trans. 2007;35(Pt 5):1142-1146.

75. Motterlini R, Otterbein LE. The therapeutic potential of carbon monoxide. Nat Rev Drug Discov. 2010;9(9):728-743.

76. Scragg JL, Dallas ML, Wilkinson JA, Varadi G, Peers C. Carbon monoxide inhibits L-type $\mathrm{Ca} 2+$ channels via redox modulation of key cysteine residues by mitochondrial reactive oxygen species. $J$ Biol Chem. 2008;283(36):24412-24419.

77. Dallas ML, Boyle JP, Milligan CJ, et al. Carbon monoxide protects against oxidant-induced apoptosis via inhibition of Kv2.1. FASEB $J$. 2011;25(5):1519-1530.

78. Nielsen VG, Pearson EC, Smith MC. Increased carbon monoxide production by hemeoxygenase-1 caused by device-mediated hemolysis: thrombotic phantom menace? Artif Organs. 2013;37(11):1008-1014.

79. Arkebauer MR, Kanaparthy SS, Malayaman SN, Vosseller K, Nielsen VG. Carbon monoxide and nitric oxide modulate $\alpha$-antiplasmin and plasmin activity: role of heme. Blood Coagul Fibrinolysis. 2011;22(8):712-719.

80. Nielsen VG, Cohen JB, Malayaman SN, Nowak M, Vosseller K. Fibrinogen is a heme-associated, carbon monoxide sensing molecule: a preliminary report. Blood Coagul Fibrinolysis. 2011;22(5):443-447.

81. Berk PD, Howe RB, Bloomer JR, Berlin NI. Studies of bilirubin kinetics in normal adults. $J$ Clin Invest. 1969;48(11):2176-2190.

82. Blanckaert N, Fevery J. Physiology and pathophysiology of bilirubin metabolism. In: Zakim D, Boyer TD, editors. Hepatology: A textbook of Liver Disease. Volume 1. 2nd ed. Philadelphia: WB Saunders; 1990:254-302.

83. Dickerson JW, Widdowson EM. Chemical changes in skeletal muscle during development. Biochem J. 1960;74:247-257.

84. Kagen LJ, Christian CL. Immunologic measurements of myoglobin in human adult and fetal skeletal muscle. Am J Physiol. 1966;211(3):656-660.

85. Vreman HJ, Stevenson DK. Heme oxygenase activity as measured by carbon monoxide production. Anal Biochem. 1988;168(1):31-38.

86. Ishikawa K, Navab M, Leitinger N, Fogelman AM, Lusis AJ. Induction of heme oxygenase-1 inhibits the monocyte transmigration induced by mildly oxidized LDL. J Clin Invest. 1997;100(5):1209-1216.

87. Ponka P. Cell biology of heme. Am J Med Sci. 1999;318(4):241-256.

88. Zheng J, Tian Q, Hou W, Watts JA, Schrum LW, Bonkovsky HL. Tissuespecific expression of ALA synthase-1 and heme oxygenase- 1 and their expression in livers of rats chronically exposed to ethanol. FEBS Lett. 2008;582(13):1829-1834. 
89. Berk PD, Bloomer JR, Howe RB, Blaschke TF, Berlin NI. Bilirubin production as a measure of red cell life span. J Lab Clin Med. 1972; 79(3):364-378.

90. Ajioka RS, Phillips JD, Kushner JP. Biosynthesis of heme in mammals. Biochim Biophys Acta. 2006;1763(7):723-736.

91. Balaban RS, Mootha VK, Arai A. Spectroscopic determination of cytochrome c oxidase content in tissues containing myoglobin or hemoglobin. Anal Biochem. 1996;237(2):274-278.

92. Qiu Y, Sutton L, Riggs AF. Identification of myoglobin in human smooth muscle. J Biol Chem. 1998;273(36):23426-23432.

93. Leffler CW, Parfenova H, Fedinec AL, Basuroy S, Tcheranova D. Contributions of astrocytes and $\mathrm{CO}$ to pial arteriolar dilation to glutamate in newborn pigs. Am J Physiol Heart Circ Physiol. 2006;291(6): H2897-H2904.

94. Zahs KR, Wu T. Confocal microscopic study of glial-vascular relationships in the retinas of pigmented rats. J Comp Neurol. 2001;429(2):253-269.

95. Krogh A. The number and distribution of capillaries in muscles with calculations of the oxygen pressure head necessary for supplying the tissue. J Physiol. 1919;52(6):409-415.

96. Hart MN, Heistad DD, Brody MJ. Effect of chronic hypertension and sympathetic denervation on wall/lumen ratio of cerebral vessels. Hypertension. 1980;2(4):419-423.

97. Staszyk C, Bohnet W, Gasse H, Hackbarth H. Blood vessels of the rat tail: a histological re-examination with respect to blood vessel puncture methods. Lab Anim. 2003;37(2):121-125.

98. Heistad DD, Marcus ML. Role of vasa vasorum in nourishment of the aorta. Blood Vessels. 1979;16(5):225-238.

99. Wolinsky H, Glagov S. Nature of species differences in the medial distribution of aortic vasa vasorum in mammals. Circ Res. 1967;20(4):409-421.

100. Cussler EL. Diffusion - Mass Transfer in Fluid Systems. 2nd ed. Cambridge: University of Cambridge; 1997.

101. Lenzi GL, Frackowiak RS, Jones T, et al. CMRO2 and CBF by the oxygen-15 inhalation technique. Results in normal volunteers and cerebrovascular patients. Eur Neurol. 1981;20(3):285-290.

102. Kanu A, Whitfield J, Leffler CW. Carbon monoxide contributes to hypotension-induced cerebrovascular vasodilation in piglets. Am J Physiol Heart Circ Physiol. 2006;291(5):H2409-H2414.

103. Beckman JD, Belcher JD, Vineyard JV, et al. Inhaled carbon monoxide reduces leukocytosis in a murine model of sickle cell disease. Am J Physiol Heart Circ Physiol. 2009;297(4):H1243-H1253.
104. Wegiel B, Gallo D, Csizmadia E, et al. Carbon monoxide expedites metabolic exhaustion to inhibit tumor growth. Cancer Res. 2013;73(23):7009-7021.

105. Zuckerbraun BS, Chin BY, Wegiel B, et al. Carbon monoxide reverses established pulmonary hypertension. J Exp Med. 2006;203(9):2109-2119.

106. Wegiel B, Hedblom A, Li M, et al. Heme oxygenase-1 derived carbon monoxide permits maturation of myeloid cells. Cell Death Dis. 2014;5:e1139.

107. Kuramitsu K, Gallo D, Yoon M, et al. Carbon monoxide enhances early liver regeneration in mice after hepatectomy. Hepatology. 2011;53(6):2016-2026.

108. Wise D, Houghton G. Diffusion coefficients of neon, krypton, xenon, carbon monoxide and nitric oxide in water at 10-60 C. Chem Eng Sci. 1968;23(10):1211-1216.

109. Kawashiro T, Nüsse W, Scheid P. Determination of diffusivity of oxygen and carbon dioxide in respiring tissue: results in rat skeletal muscle. Pflugers Arch. 1975;359(3):231-251.

110. Maines MD. Heme oxygenase: function, multiplicity, regulatory mechanisms, and clinical applications. FASEB J. 1988;2(10):2557-2568.

111. Morimoto Y, Durante W, Lancaster DG, Klattenhoff J, Tittel FK. Realtime measurements of endogenous $\mathrm{CO}$ production from vascular cells using an ultrasensitive laser sensor. Am J Physiol Heart Circ Physiol. 2001;280(1):H483-H488.

112. Mentré P, Escaig F. Preservation of the diffusible cations for secondary ion mass spectrometry. II. Artefacts in material embedded in araldite or melamine. Biol Cell. 1992;74(1):119-126.

113. Leffler CW, Balabanova L, Fedinec AL, Parfenova H. Nitric oxide increases carbon monoxide production by piglet cerebral microvessels. Am J Physiol Heart Circ Physiol. 2005;289(4):H1442-H1447.

114. Nathanson JA, Scavone C, Scanlon C, McKee M. The cellular Na+ pump as a site of action for carbon monoxide and glutamate: a mechanism for long-term modulation of cellular activity. Neuron. 1995;14(4):781-794.

115. Sohlenius-Sternbeck AK. Determination of the hepatocellularity number for human, dog, rabbit, rat and mouse livers from protein concentration measurements. Toxicol In Vitro. 2006;20(8):1582-1586.

116. Iwatsubo T, Suzuki H, Sugiyama Y. Prediction of species differences (rats, dogs, humans) in the in vivo metabolic clearance of YM796 by the liver from in vitro data. J Pharmacol Exp Ther. 1997;283(2):462-469.
Clinical Pharmacology: Advances and Applications

\section{Publish your work in this journal}

Clinical Pharmacology: Advances and Applications is an international, peer-reviewed, open access journal publishing original research, reports, reviews and commentaries on all areas of drug experience in humans. The manuscript management system is completely online and includes a very quick and fair peer-review system, which is all easy to use.

\section{Dovepress}

Visit http://www.dovepress.com/testimonials.php to read real quotes from published authors. 